\title{
RESEARCH
}

Open Access

\section{THM modeling of hydrothermal circulation at Rittershoffen geothermal site, France}

Bérénice Vallier $^{1 *}$, Vincent Magnenet ${ }^{2}$, Jean Schmittbuhl ${ }^{1}$ and Christophe Fond ${ }^{2}$

*Correspondence:
vallier@unistra.fr
1EOST-IPGS, University
of Strasbourg/CNRS, 5, Rue
René Descartes, Strasbourg,
France
Full list of author information
is available at the end of the
article

article

\begin{abstract}
Background: The Rittershoffen deep geothermal project located $6 \mathrm{~km}$ east from Soultz-sous-Forts EGS site (France) includes a doublet GRT-1 and GRT-2 to exploit the geothermal resource at the sediments-granite transition where higher temperatures than those of Soultz-sous-Forêts have been measured. Detailed stratigraphic and geophysical data, temperature logs, and tracer surveys have been collected. However, no reservoir model, integrating large-scale geophysical measurements, exists for this site.

Methods: We developed a reservoir model in two dimensions $(10 \mathrm{~km} \times 5 \mathrm{~km})$ based on a finite element method. It includes thermo-hydro-mechanical (THM) coupling and extended brine properties. A representative elementary volume of $100 \mathrm{~m}$ is assumed to homogenize the fault network complexity at small scales. A back analysis is performed to obtain large-scale rock properties using GRT-1 temperature log and regional stress-depth profiles.
\end{abstract}

Results: The inverted large-scale properties are consistent with their counterparts measured at the laboratory scale. The bottom of the hydraulic cap rock is $1.2 \mathrm{~km} \pm 0.1 \mathrm{~km}$ deep. It is shallower than the discontinuity of the thermal gradient. Hydrothermal convection cells are $2.7 \mathrm{~km}$ high which is larger than that previously proposed.

Conclusions: A very good fit of the GRT-1 temperature log is obtained using our simplified two-dimensional THM model with four homogenized units at a $100 \mathrm{~m}$ scale. The comparison between Rittershoffen and Soultz-sous-Forêts models highlights many similarities in terms of rock properties, decoupling of hydraulic and thermal cap rocks and temperature spatial variability (about $50^{\circ} \mathrm{C}$ ). Predictions of the relationship between reservoir temperature and surface thermal gradients are proposed for future explorations.

Keywords: Deep geothermal reservoir, Thermal anomaly, EGS, Thermo-hydromechanical model, Hydrothermal convection 


\section{Background}

\section{Introduction}

In the Upper Rhine Graben (URG), the geothermal gradient is unusually high at the near surface (more than $100{ }^{\circ} \mathrm{C} / \mathrm{km}$ in the first kilometer in depth, whereas the main value in Europe is $30^{\circ} \mathrm{C} / \mathrm{km}$ ) (Haas and Hoffmann 1929).

The high underground temperatures in the URG make the region the most studied one in Europe for geothermal applications (Genter et al. 2016; Olasolo et al. 2016; Huenges and Ledru 2011). Geothermal projects, such as the well-known pilot research Soultzsous-Forêts site, are based on enhanced geothermal system (EGS) technology. The EGS concept consists in increasing the reservoir permeability using hydraulic, thermal and/or chemical stimulations and then forcing a circulation of the natural brines in the deep wells taking advantage of the thermal anomaly related to the large-scale hydrothermal system in fractured rocks (Tester et al. 2006; Schindler et al. 2010; Gérard et al. 2006; Schill et al. 2017). After the development (during more 25 years) of the Soultz-sous-Forêts pilot site as an EGS demonstrator, a new industrial project at Rittershoffen was initiated in 2011 and operated in 2016 (Baujard et al. 2015; Genter et al. 2015). The Rittershoffen site is located $6 \mathrm{~km}$ east from Soultz-sous-Forêts in Northern Alsace. The project is based on a geothermal doublet, GRT-1 and GRT-2, drilled around $2.6 \mathrm{~km}$ deep to intersect the normal Rittershoffen fault and its associated fracture network at the interface between sediments and granite. Structural and stratigraphic studies (Aichholzer et al. 2016; Hehn et al. 2016; Vidal et al. 2016a), temperature logs (Baujard et al. 2016, 2017) as well as seismic (Gaucher et al. 2013; Maurer et al. 2015; Lengliné et al. 2017) and geochemical surveys (Dezayes et al. 2014; Sanjuan 2016) have been already established to identify permeable zones and the hydraulic connections between GRT-1 and GRT-2 wells. The knowledge of the Rittershoffen site is also completed by the huge database collected in the nearby Soultz-sous-Forêts site. Five permeable zones have been currently identified in the granite reservoir, but none in the sediments (Vidal et al. 2016b).

As already demonstrated for the Soultz-sous-Forêts research site, numerical modelings can provide significant insights to better understand the hydrothermal circulation or the rock physics of EGS reservoirs (Jain et al. 2015; Kolditz and Clauser 1998; Pruess 1990; Sanyal 2000; Tomac 2017). Numerical reservoir models can typically be classified according to different aspects (Willis-Richards and Wallroth 1995): (i) the description of the complex fracture network geometries they integrate via stochastic distribution (Baujard and Bruel 2006; Cacas et al. 1990) or regular grids (Watanabe and Takahashi 1995; Kohl and Mégel 2007; Willis-Richards et al. 1996), (ii) the analysis of detailed physical processes such as full thermo-hydro-mechanical-chemical (THMC) couplings they account for (Kohl et al. 1995; Gelet et al. 2012; Diersch and Kolditz 1998; Bachler and Kohl 2005; McDermott et al. 2006a, b). Thermo-hydro-mechanical (THM) modeling based on a homogenized description of the reservoir has been recently presented in Magnenet et al. (2014) for the Soultz-sous-Forêts site to describe the natural hydrothermal circulation.

In the continuity of this work, the current study aims at proposing a new model of the large-scale hydrothermal circulation in the recent Rittershoffen EGS site. The numerical modeling is based on the current local geological and geophysical knowledge from Rittershoffen, but also the closeby Soultz-sous-Forêts site. The 2D reservoir model includes 
all major THM couplings. The equations governing THM processes are solved by a finite element approach using the Code_Aster software. The reservoir is homogenized at the scale of $100 \mathrm{~m}$. The fluid rheology (e.g., density, viscosity, heat capacity) is considered as dependent on temperature and fluid pressure as shown by laboratory measurements (Zaytsev and Aseyev 1992; Kestin et al. 1981; Rowe and Chou 1970). We include different a priori settings: (i) the main geological structures of the sedimentary cover (Aichholzer et al. 2016) and the basement (Vidal et al. 2016a), (ii) the temperature-depth profiles through the deep boreholes GRT-1 and GRT-2 (Baujard et al. 2017), (iii) the distribution of the natural radioactivity (Rummel 1992; Pribnow et al. 1999; Pribnow and Schellschmidt 2000), (iv) the regional stress-state (Evans et al. 2009; Cornet et al. 2007; Valley 2007), (v) the rock properties and their up-scaling (GeORG13), and (vi) the geochemical data obtained from brine samples (Sanjuan 2016). We proceed to a back analysis to find the reservoir parameters from the temperature and stress logs. We finally compare the results with the insights from the Soultz-sous-Forêts site and discuss the impact of the geological settings and large-scale fault on the hydrothermal circulation, the location of the hydraulic and thermal cap rocks, the lateral variability of the reservoir temperature and the link between the geothermal gradient and the reservoir temperature at a depth of $2.0 \mathrm{~km}$.

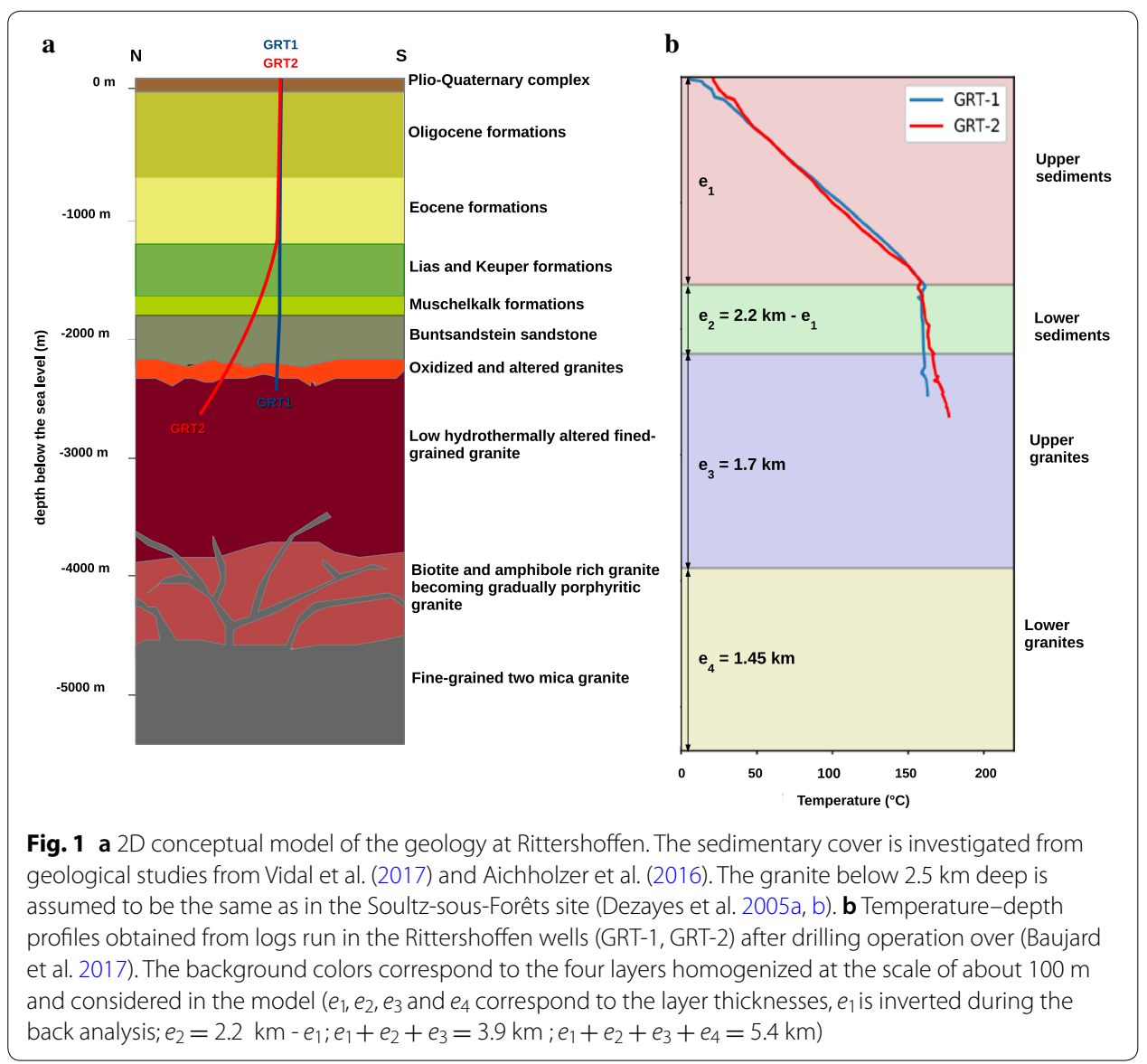




\section{Presentation of the Rittershoffen site Geological settings}

Figure 1a shows a representation of the main geological units of the Rittershoffen site. Its geology is similar to those of Soultz-sous-Forêts site except for the thicknesses of the units (Aichholzer et al. 2016). At Rittershoffen, the first 2200 meters consists of a sedimentary cover overlying a granitic basement, whereas the interface sedimentsgranite is at $1400 \mathrm{~m}$ for the Soultz-sous-Forêts site. The sedimentary sequence begins by a sandy-clayey Pliocene-Quaternary layer. This layer is thicker by about $530 \mathrm{~m}$ at Rittershoffen than at Soultz-sous-Forêts due to a higher erosion rate in the latter. The Pliocene-Quaternary sequence directly lays on clays and marls of the Oligocene age. Contrary to Soultz-sous-Forêts, the Rittershoffen site exhibits a full Grey Series complex and an upper part of the Pechelbronn layers. Below, Eocene formations are composed of two units: ferruginous marls of the red layer and clayey marlstones interbedded with domolite layers (i.e., the dolomitic zone). The dolomitic zone is also thicker in Rittershoffen than in Soultz-sous-Forêts. The Tertiary unit is overlying Jurassic formations that include Dogger black silty clay shales and Lias gray clay formations. The Triassic sequence is the deepest part of the sedimentary cover. The Triassic units are thicker in Rittershoffen than in Soultz-sous-Forêts. It corresponds to Keuper marls and clays, Muschelkalk limestones and marly calcareous dolomites. The last Triassic layer corresponds to the Buntsandstein sandstone.

Core studies show that the top of the granitic basement is divided into three parts (Vidal et al. 2017). From the top to the bottom, it is composed of reddish oxidized granite due to paleo-weathering, hydrothermally altered granite and fine-grained low altered granite. Here, we assume that after $2.5 \mathrm{~km}$ in depth, the granitic basement is the same in Rittershoffen as in Soultz-sous-Forêts. The basement until $3.9 \mathrm{~km}$ deep is composed of a porphyritic monzo-granite with K-feldspar megacrysts in Soultz-sous-Forêts (Dezayes et al. 2010, 2005c). Located below this is the first transition at about $3.9 \mathrm{~km}$ to a biotite and amphibole enriched granite and the second transition at about $4.6 \mathrm{~km}$ to a rather different leuco-granite with very finegrained micas.

Ultra borehole images (UBIs) logs and geochemical analyses have been performed to investigate the structural properties of the fracture networks in Rittershoffen (Vidal et al. 2016a; Dezayes et al. 2014; Vidal et al. 2017). As in Soultz-sous-Forêts, two main natural fracture systems have been identified (Dezayes et al. 2014). The first is composed of closely connected meso-fractures. The second is a set of large fractures crossing the former system. From structural analysis, the main set of fractures is oriented around $\mathrm{N} 15-20^{\circ} \mathrm{E}$ with a dip of $80^{\circ} \mathrm{W}$ in GRT-1, but more scattered in GRT-2. In the sediments, the density of fractures is about 0.33 fractures per meter. Among eight major fracture areas (i.e., with a thickness higher than $1 \mathrm{~cm}$ ), only one fracture cluster is considered as permeable (Vidal et al. 2016b). It has an orientation of $\mathrm{N} 20^{\circ} \mathrm{E}$ with a dip of $85^{\circ} \mathrm{W}$. In contrast, the top of the basement is highly fractured with about 2.51 fractures per meter, even more than in Soultz-sous-Forêts (with 0.65 fractures per meter). Four permeable fracture areas have been observed among 11 major fracture zones. The fracture zones in the granite have the same orientation as in the Soultz-sous-Forêts site, parallel to the regional orientation. 


\section{Temperature profiles and hydrothermal circulation}

Figure $1 \mathrm{~b}$ illustrates the temperature-depth profiles in GRT-1 and GRT-2 (Baujard et al. 2017). From the surface to the top of the Muschelkalk, the geothermal gradient is constant (around $85^{\circ} \mathrm{C} \mathrm{km}^{-1}$ ) in both wells. The value is slightly lower than in Soultz-sousForêts where it is about $110^{\circ} \mathrm{C} \mathrm{km}^{-1}$. Below, the geothermal gradient suddenly declines about 30 times, i.e., around $3{ }^{\circ} \mathrm{C} \mathrm{km}^{-1}$ in GRT- 1 and about $18{ }^{\circ} \mathrm{C} \mathrm{km}^{-1}$ in GRT-2 at the time of the measurement. The difference in geothermal gradient between the two wells is explained by the thermal non-equilibrium of the GRT-2 well (Baujard et al. 2016). Some local temperature perturbations have been recorded in the profiles between 1500 and $2700 \mathrm{~m}$ in depth. They are commonly considered as evidence of hydrothermal circulation through fracture zones in particular around 1650 and $2350 \mathrm{~m}$ deep in GRT-1. The temperature evolution with depth is unknown below the bottom of the wells. Temperature logs in Soultz-sous-Forêts suggest that the geothermal gradient tends to the average Central European gradient (around $30{ }^{\circ} \mathrm{C} \mathrm{km}^{-1}$ ) in the deep granitic basement (Genter et al. 2010; Pribnow et al. 1999). From the surface to the top of the Muschelkalk, the linear temperature trend suggests that the thermal state is purely diffusive.

The sharpness of the transition at $1.65 \mathrm{~km}$ deep would imply that the upper sediments behave as a hydraulic cap rock. Below, the very low geothermal gradient is classically interpreted as the result of an active and large-scale hydrothermal convection within the fractured granite. Indeed, an intense circulation of the native brine has been evidenced in the reservoir from geochemical analyses of the in situ fluid in GRT-1 and GRT-2 (Dezayes et al. 2014; Sanjuan 2016). The low tracer concentrations in GRT-2 during an injection test in GRT-1 highlight a weaker connection between the wells than in Soultz-sous-Forêts (Sanjuan 2016). However, we will show in the present study that this interpretation is oversimplified and has to be reconsidered. The fluid analysis indicates that natural brine has the same salinity, $\mathrm{pH}$ and chemical characteristics as in Soultz-sous-Forêts.

The contribution of natural granite radioactivity to the origin of the thermal anomaly in the Upper Rhine Graben has been studied from core analyses at the Soultzsous-Forêts site (Rummel 1992; Pribnow et al. 1999; Pribnow and Schellschmidt 2000; Baillieux et al. 2013). The production rates are typically of the order of $0.1,1.0,5.0 \mu$ $\mathrm{W} \mathrm{m}{ }^{-3}$, respectively, for the upper sediments, the Buntsandstein sandstone and the two granites (Kohl 2000). We will assume that they are similar at Rittershoffen.

\section{Rock physics}

No direct laboratory measurements of the sediments and granite properties are available for the Rittershoffen site. This is why the rock properties at Rittershoffen are assumed to be the same as at the vicinity of the Soultz-sous-Forêts site. Table 1 presents a synthetic review of the relevant rock properties obtained either from laboratory measurements on core samples or from geophysical investigations. Thermal conductivities vary between 1.1 and $5.9 \mathrm{~W} \mathrm{~m}^{-1} \mathrm{~K}^{-1}$ (GeORG 2013) and permeabilities between $1.0 \times 10^{-20}$ and $3.2 \times 10^{-12} \mathrm{~m}^{2}$ with a large variability which will be used as prior distribution for the back analysis (Hettkamp et al. 1999; Kohl 2000; Bar 2012; GeORG 2013; Magnenet et al. 2014; Griffiths et al. 2016; Heap et al. 2017). 
Table 1 Typical rock properties according to: (1) Magnenet et al. (2014); (2) Kohl (2000); (3) GeORG); (4) Bar (2012); (5) Rummel (1992); (6) Haenel (1983); (7) Freymark et al. (2017); (8) Kirk and Williamson (2012); (9) Sausse (2002); (10) Heap et al. (2017); (11) Griffiths et al. (2016); (12) Hettkamp et al. (1999)

\begin{tabular}{|c|c|c|c|c|}
\hline Property (unit) & Upper sediments & Lower sediments & Upper granites & Lower granites \\
\hline Porosity, $\phi_{0}(\%)$ & $3.0^{[1]}-35.0^{[1]}$ & $2.9^{[10]}-20.7^{[11]}$ & $0.13^{[3]}-25.55^{[3]}$ & $0.13^{[3]}-0.8^{[1]}$ \\
\hline $\begin{array}{l}\text { Total specific mass, } r_{0} \\
\left(\mathrm{~kg} \mathrm{~m}^{-3}\right)\end{array}$ & $2300^{[1]}-2600^{[1]}$ & $2180^{[4]}-2660^{[7]}$ & $2500^{[1]}-2800^{[1]}$ & $2650^{[6]}-2800^{[6]}$ \\
\hline $\begin{array}{l}\text { Young's modulus, } E \\
\text { (GPa) }\end{array}$ & $10.0^{[1]}-90.0^{[1]}$ & $8.0^{[1]}-39.0^{[5]}$ & $25.0^{[9]}-80.0^{[5]}$ & $25.0^{[9]}-80.0^{[5]}$ \\
\hline Poisson's ratio, $v(-)$ & $0.1^{[9]}-0.33^{[1]}$ & $0.06^{[1]}-0.46^{[1]}$ & $0.1^{[9]}-0.38^{[5]}$ & $0.1^{[9]}-0.38^{[5]}$ \\
\hline Biot coefficient, $b(-)$ & $0.65^{[1]}-0.8^{[1]}$ & $0.8^{[1]}-1.0^{[1]}$ & $0.27^{[1]}-0.45^{[1]}$ & $0.27^{[1]}-0.45^{[1]}$ \\
\hline $\begin{array}{l}\text { Specific heat, } c_{s} \\
\left(J \mathrm{~kg}^{-1} \mathrm{~K}^{-1}\right)\end{array}$ & $800^{[1]}$ & $800^{[1]}$ & $800^{[1]}$ & $800^{[1]}$ \\
\hline $\begin{array}{l}\text { Thermal conductivity, } \\
\lambda_{d}\left(\mathrm{~W} \mathrm{~m}^{-1} \mathrm{~K}^{-1}\right)\end{array}$ & $1.1^{[3]}-5.9^{[3]}$ & $1.2^{[3]}-4.2^{[3]}$ & $2.3^{[3]}-4.3^{[3]}$ & $2.3^{[3]}-4.3^{[3]}$ \\
\hline $\begin{array}{l}\text { Thermal dilation, } \alpha_{0} \\
\left(10^{-5} \mathrm{~K}^{-1}\right)\end{array}$ & $1.3^{[8]-1.5^{[8]}}$ & $1.3^{[8]}-1.5^{[8]}$ & $1.4^{[1]}$ & $1.4^{[1]}$ \\
\hline 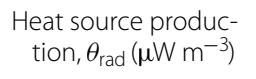 & $0.1^{[2 L}-1.0^{[3]}$ & $0.5^{[1]}-1.0^{[3]}$ & $1.0^{[6]}-6.2^{[5]}$ & $1.0^{[6]}-6.2^{[5]}$ \\
\hline Permeability, $K_{\text {int }}\left(m^{2}\right)$ & $\begin{array}{l}1.0 \times 10^{-18^{[4]}} \\
\quad-3.2 \times 10^{-14^{[4]}}\end{array}$ & $\begin{array}{l}1.0 \times 10^{-18^{[11]}} \\
-1.0 \times 10^{-13^{[10]}}\end{array}$ & $\begin{array}{l}1.0 \times 10^{-20^{[12]}} \\
-3.0 \times 10^{-14^{[12]}}\end{array}$ & $\begin{array}{l}1.0 \times 10^{-20^{[12]}} \\
-1.8 \times 10^{-15^{[3]}}\end{array}$ \\
\hline
\end{tabular}

\section{Toward a large-scale reservoir model at Rittershoffen}

The goal of the study is to build the simplest THM numerical model that is consistent with the main characteristics of the Rittershoffen site. The model does not aim to describe all the complexity of the geology or the deterministic details of the faults networks (Fig. 1a). As sketched in Fig. 1b, the whole sedimentary cover is split into two horizontal homogenized units: the upper sediments and the lower sediments. The depth of the transition between the two units is taken as a parameter to be adjusted (named $e_{1}$ ) during the parameter back analysis. The basement is also split into two units: the upper granites and the lower granites. Due to the lack of direct knowledge on the deep granitic basement in Rittershoffen, the transition between the two units is set at a depth $e_{1}+e_{2}+e_{3}=3.9 \mathrm{~km}$ as in Soultz-sous-Forêts site. The transition between the sediments and the granite is also set at $e_{1}+e_{2}=2.2 \mathrm{~km}$ in depth. We assume that the radiogenic sources are set at $0.1,1.0,5.0 \mu \mathrm{W} \mathrm{m}{ }^{-3}$, respectively, for the upper sediments, the lower sediments and the two granites (Kohl 2000).

\section{Methods}

\section{Governing equations of the THM model}

All units are homogenized as a porous medium, fully saturated with a single-phase brine and including thermo-hydro-mechanical (called THM) coupling as developed in Coussy (2004). Here are our main assumptions:

- A small perturbation assumption is made and solid grains are considered to remain in the thermo-elastic regime;

- The Cauchy stress tensor $\sigma$ is split into two contributions: an effective stress $\sigma^{\prime}$ and a hydraulic stress $\sigma_{p} \mathbf{1}$ ( $\mathbf{1}$ being the unit tensor); 
- The thermodynamic flows (effective Cauchy stress $\sigma^{\prime}$, water surface mass flow $\mathbf{M}_{w}$, heat flow $\mathbf{q}$ ) are lineary related to thermodynamic forces (linearized strain $\epsilon$, gradient of pore pressure $\nabla p_{w}$, gradient of temperature $\nabla T$ ), but with coefficients that may depend on temperature, porosity (denoted here $\phi$ ) or pore pressure. Hence, most of the homogenized properties (such as the specific heat at constant stress and the thermal conductivity) appearing in Hooke's law, Darcy's law, and Fourier's law of the porous materials are considered as functions of the form $f\left(\phi, p_{w}, T\right)$ by using classical mixing laws;

- Following the approach of Magnenet et al. (2014) and Vallier et al. (2016), we consider a rheology of brine that is extrapolated from experimental results for artificial brines at different salinities ( $\mathrm{NaCl}$ ) (Zaytsev and Aseyev 1992; Kestin et al. 1981; Rowe and Chou 1970). More specifically, we assume that the natural brine is equivalent to a pure $\mathrm{NaCl}$ solution with a mean specific mass content of $100 \mathrm{~g} \mathrm{~L}^{-1}$. The retained mathematical expressions of the brine properties (density, dynamic viscosity, thermal dilatation, thermal conductivity) are given in Table 2.

The whole set of notations as well as a detailed presentation of the governing equations is presented in Appendix 1.

\section{The finite-element model}

The governing equations are solved by using the open-source finite element solver Code Aster, (EDF, 2016; Zienkiewicz et al. 2013) in which specific developments were added to account for the heat sources induced by the radioactivity of rocks, the nonlinear rheology of brine and the search of the stationary solutions. Figure 2 shows the considered cross section of the four idealized units from our Rittershoffen reservoir model (Fig. 1b).

Table 2 Review of the constitutive equations of the brine properties and values of empirical coefficients

\begin{tabular}{|c|c|c|}
\hline Parameter & Expression & Coefficients \\
\hline Density, $\rho_{w}^{0}\left(\mathrm{~kg} \mathrm{~m}^{-3}\right)$ & 1070 & - \\
\hline Bulk modulus, $K_{w}(\mathrm{GPa})$ & 2.2 & - \\
\hline Dynamic viscosity, $\mu_{W}$ (Pa s) & $\mu_{w}^{\infty}+\Delta \mu_{w}^{\infty} \exp \left(\beta\left(T-T_{\text {ref }}\right)\right)$ & $\begin{array}{l}\mu_{W}^{\infty}=1.9 \times 10^{-4}(\mathrm{~Pa} \mathrm{~s}) \\
\Delta \mu_{W}^{\infty}=6.2 \times 10^{-6}(\mathrm{~Pa} \mathrm{~s}) \\
\beta=-0.02 \mathrm{~K}^{-1} \\
\mathrm{~T}_{\text {ref }}=406.4 \mathrm{~K}^{-1}\end{array}$ \\
\hline Heat capacity, $c_{w}^{p}\left(\mathrm{~J} \mathrm{~kg}^{-1} \mathrm{~K}^{-1}\right)$ & $a_{c_{w}^{p}}+b_{c_{w}^{p}}\left(T-T^{1}\right)+c_{c_{w}^{p}}\left(T-T^{1}\right)^{2}$ & $\begin{array}{l}a_{c_{w}^{p}}=3.7\left(\mathrm{~J} \mathrm{~kg}^{-1} \mathrm{~K}^{-1}\right) \\
b_{c_{w}^{p}}=0.4\left(\mathrm{~J} \mathrm{~kg}^{-1} \mathrm{~K}^{-2}\right) \\
c_{c_{w}^{p}}=4.6 \times 10^{-3}\left(\mathrm{~J} \mathrm{~kg}^{-1} \mathrm{~K}^{-3}\right) \\
T^{1}=273.15 \mathrm{~K}\end{array}$ \\
\hline Thermal dilation, $\alpha_{W}\left(K^{\top}\right)$ & $a_{\alpha_{W}}+2 b_{\alpha_{W}}\left(T-T^{0}\right)+3 c_{\alpha_{W}}\left(T-T^{0}\right)^{2}$ & $\begin{array}{l}a_{\alpha_{w}}=1.3 \times 10^{-4} \mathrm{~K}^{1} \\
b_{\alpha_{w}}=4.3 \times 10^{-1} \mathrm{~K}^{2} \\
c_{\alpha_{w}}=2.5 \times 10^{-10} \mathrm{~K}^{3} \\
\mathrm{~T}^{\circ}=293.0 \mathrm{~K}\end{array}$ \\
\hline Thermal conductivity, $\lambda_{w}\left(W m^{-1} K^{-1}\right)$ & $a_{\lambda_{W}}\left[1-b_{\lambda_{w}} \exp \left(-c_{\lambda_{W}}\left(T-T^{1}\right)\right]\right.$ & $\begin{array}{l}a_{\lambda_{W}}=0.7\left(\mathrm{Wm}^{-1} \mathrm{~K}^{-1}\right) \\
b_{\lambda_{W}}=0.2 \\
c_{\lambda_{W}}=0.02 \mathrm{~K}^{-1}\end{array}$ \\
\hline
\end{tabular}




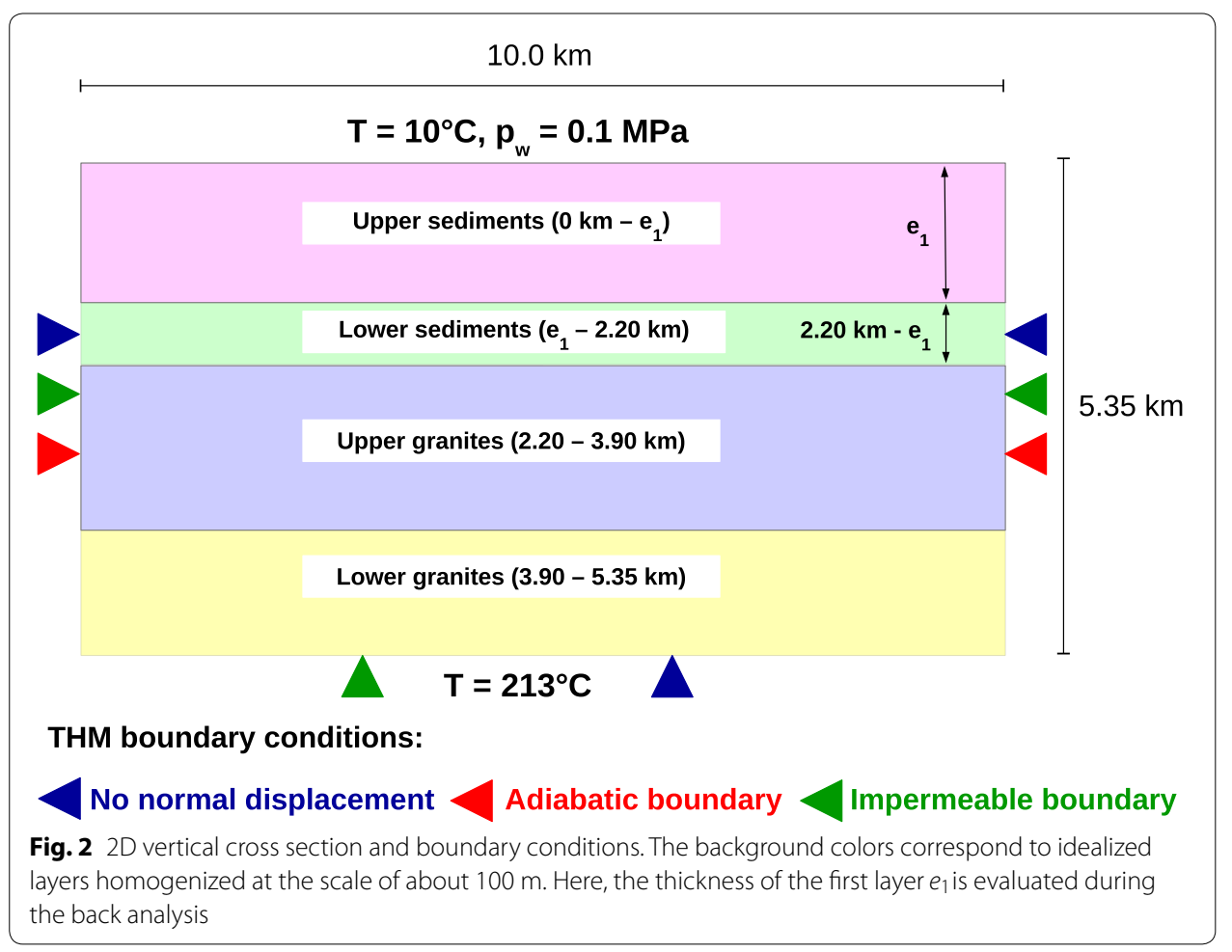

This idealized cross section is $5.35 \mathrm{~km}$ in height and $10 \mathrm{~km}$ in width and contains no large-scale fault. Below, we denote by $x$ the horizontal direction, $z$ the out-of-plane horizontal direction and $y$ the vertical one. The typical size of elements is $100 \mathrm{~m} \times 100 \mathrm{~m}$. Consequently, the rheological properties taken as inputs as the model are homogenized at this length scale. In Fig. 2, the boundary conditions used in our numerical simulations are also summarized:

- Temperatures are, respectively, maintained at 10.0 and $213.0{ }^{\circ} \mathrm{C}$ on the upper and lower boundaries. The lateral boundaries are taken as adiabatic.

- A fluid pressure of 0.1 MPa (i.e., the value of atmospheric pressure) is imposed on the upper boundary. The other boundaries are assumed to be impermeable.

- The normal displacement is nil on the lower and lateral boundaries. The upper boundary is stress free.

A Euler implicit scheme is used for the time integration of nodal mechanical displacements, pore pressures and temperatures. The nonlinear system is solved by the Newton-Raphson method.

For the initial conditions, a constant and uniform temperature of $10.0^{\circ} \mathrm{C}$ is assumed. The fluid pressure field is also assumed to be constant at $0.1 \mathrm{MPa}$. To ensure the convergence of the process, the computation has been divided into three steps (Magnenet et al. 2014): (i) during a short time period of 1000 years, the boundary conditions and gravity are progressively applied ; (ii) next, during 100,000 years, the system freely evolves along constant boundary conditions ; (iii) in one last increment, the system reaches a steady state by cancelling the nonstationary terms from the constitutive equations. 


\section{Inverse method}

In this study, some geometrical and rheological parameters are estimated by back analysis (see next section). To do it, Code_Aster has been coupled to the Parameter ESTimation (PEST) software (Doherty 2005).

Numerous inverse methods have been established to carry out back analysis of the rock properties: Monte-Carlo methods, Bayesian approaches which associate probability distribution for each parameter (Vogt 2012; Kosack et al. 2011; Tarantola 2004), the neighborhood algorithm based on random generation of new parameters (Sambridge 1999) or the genetic algorithm (Pérez-Flores and Schultz 2002).

Here, the PEST back analysis software is an implementation of the so-called Levenberg-Marquardt algorithm which minimizes an "error function" - typically the $L_{2}$-norm of the difference between model and observations-with respect to a chosen set of parameters. Each parameter $p$ is taken from a uniform a priori distribution called prior distribution in the range $\left[p_{\min }, p_{\max }\right]$ chosen to be wider than experimental values (see Table 1).

The main benefit of our back analysis is that the inversion procedure based on deterministic method is less numerically intensive than the stochastic methods. However, the inversion procedure is sensitive to the initial conditions of the back analysis such as the prior distributions of the rock properties. Nonetheless, the prior distributions are well constrained thanks to databases from Rittershoffen and Soultz-sous-Forêts sites.

In the current study, we aim to estimate four rock properties : permeability, thermal conductivity and elastic moduli (i.e., Young's modulus and Poisson's ratio) by inverting the observed temperature and stress profiles with depth using the THM model as the forward model. During this back analysis, the four rock properties are explored in the prior uniform distributions described in Table 3. The prior distributions, wider than the variability of the data, allow the inversion to explore all the relevant experimental values for the Rittershoffen site. Other rock properties described in Table 1 are set as constant during the back analysis. Their values are summarized in Table 4.

Table 3 Ranges of tested values during the back analysis called "prior distributions"

\begin{tabular}{lllll}
\hline Property (unit) & Upper sediments & Lower sediments & Upper granite & Lower granite \\
\hline Permeability $K_{\text {int }}\left(\mathrm{m}^{2}\right)$ & $10^{-21}-10^{-15}$ & $10^{-21}-10^{-15}$ & $10^{-21}-10^{-11}$ & $10^{-21}-10^{-11}$ \\
Thermal conductivity $\lambda_{d}\left(\mathrm{~W} \mathrm{~m}^{-1} \mathrm{~K}^{-1}\right)$ & $0.4-6.5$ & $0.4-6.5$ & $0.4-6.5$ & $0.4-6.5$ \\
Young's modulus $E(\mathrm{GPa})$ & $5.0-95.0$ & $5.0-95.0$ & $5.0-95.0$ & $5.0-95.0$ \\
Poisson's ratio $v(-)$ & $0.05-0.49$ & $0.05-0.49$ & $0.05-0.49$ & $0.05-0.49$ \\
\hline
\end{tabular}

Table 4 Values of the rock properties fixed during the back analysis

\begin{tabular}{lllll}
\hline Property (unit) & $\begin{array}{l}\text { Upper } \\
\text { sediments }\end{array}$ & Lower sediments & Upper granite & Lower granite \\
\hline Porosity $\phi_{0}(\%)$ & 9.0 & 9.0 & 3.0 & 0.3 \\
Total specific mass $r_{0}\left(\mathrm{~kg} \mathrm{~m}^{-3}\right)$ & 2390 & 2390 & 2690 & 2690 \\
Biot coefficient $b(-)$ & 0.73 & 0.90 & 0.36 & 0.36 \\
Specific heat $c_{S}\left(\mathrm{~J} \mathrm{~kg}^{-1} \mathrm{~K}^{-1}\right)$ & 800.0 & 800.0 & 800.0 & 800.0 \\
Thermal dilation $\alpha_{0}\left(10^{-5} \mathrm{~K}^{-1}\right)$ & 1.4 & 1.4 & 1.4 & 1.4 \\
Heat source production $\theta_{\mathrm{rad}}\left(\mu \mathrm{W} \mathrm{m}^{-3}\right)$ & 0.1 & 1.0 & 5.0 & 5.0 \\
\hline
\end{tabular}


During the PEST inversion, several assumptions have been made:

- The depth of the granitic basement is taken as the same as in Soultz-sous-Forêts. More precisely, the interface between the upper and lower granites is set at the depth $e_{1}+e_{2}+e_{3}=3.9 \mathrm{~km}$. We also set the interface between sediments and granite at $e_{1}+e_{2}=2.2 \mathrm{~km}$.

- The ranges of values of rock properties are assumed to be the same as in Soultz-sousForêts (see Table 1).

- The observed temperature profile is assumed to be at the location of the surface maximum heat flux. This assumption is consistent with surface temperature maps in the Rittershoffen area (Haas and Hoffmann 1929). In practice, the numerical temperature profile has then been calculated at the side of a convective cell where the Darcy's velocity is purely ascending. The stress-depth profiles are taken from the same position.

\section{Results of the back analysis}

The goal of the study is to better understand the physics of the Rittershoffen reservoir. To address this issue, a back analysis confronting our THM model with the observed temperature and stress depth profiles is carried out. To reproduce the GRT-1

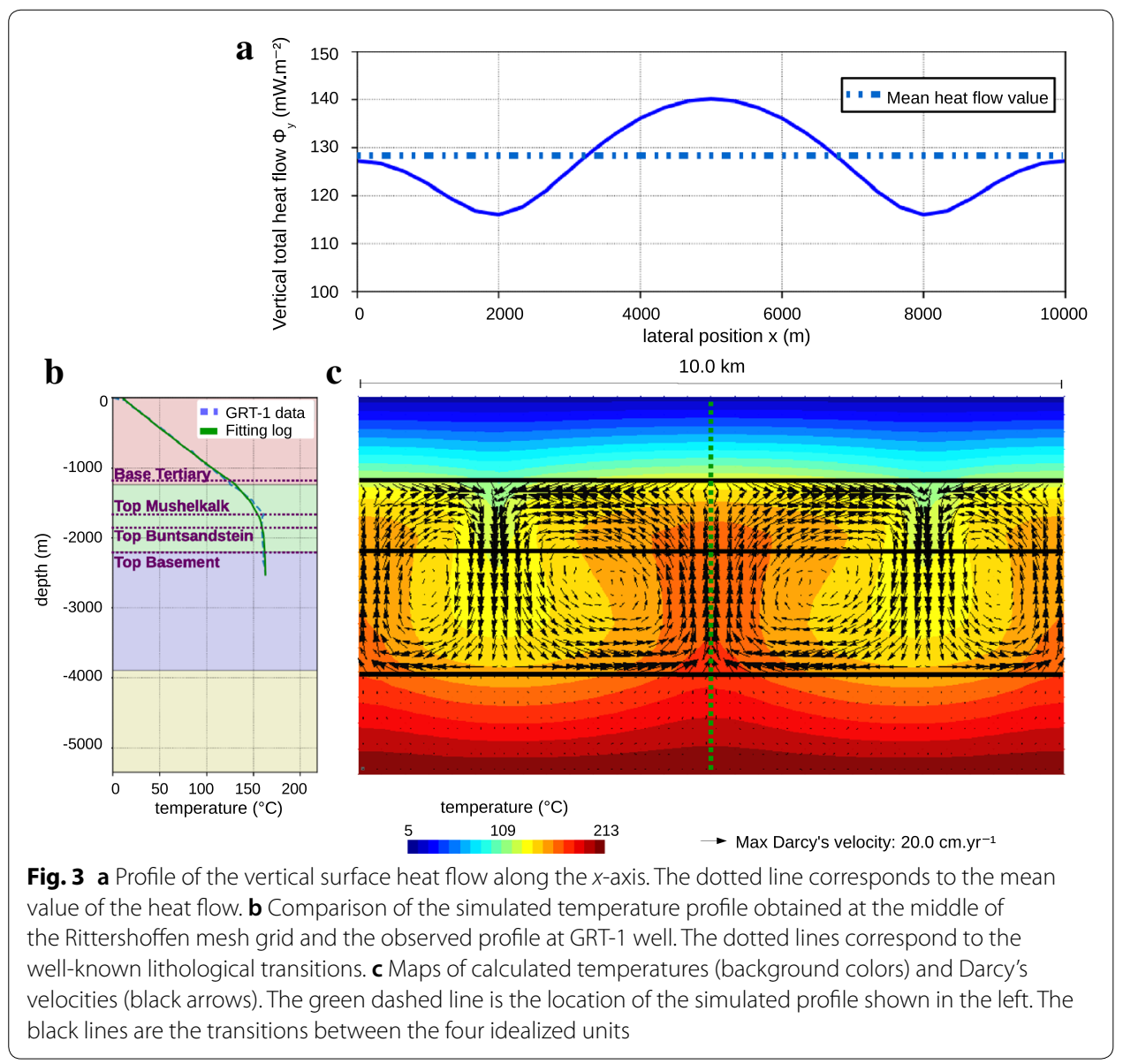


temperature-depth profile, nine parameters are estimated: the thickness of the first geological layer $e_{1}$, and the permeabilities $K_{\mathrm{int}, i}$ and thermal conductivities $\lambda_{i}$ of the four layers $i=1 \ldots 4$.

An excellent fit was found between the simulated temperature-depth profile and the measured GRT-1 one. The main trend of the observed T-log (except for the sharpness observed around $1.65 \mathrm{~km}$ deep), the temperature gradients and the reservoir temperature around $160{ }^{\circ} \mathrm{C}$ are well reproduced. The temperature and Darcy's velocity maps of the best model are displayed in Fig. 3. The convection cells have a width of about $3.0 \mathrm{~km}$ and a height of $2.7 \mathrm{~km}$. The maximum of Darcy's velocity is about $20.0 \mathrm{~cm}$ year $^{-1}$. The hydraulic cap rock corresponds to a contrast of permeability and isolates the hydrothermal circulation as convection below. The depth of the top of the convection cells is the depth of the hydraulic cap rock. By analogy, the thermal cap rock corresponds to a contrast of thermal conductivity. Here, the hydraulic cap rock (i.e., the top of the convection cells) appears shallower than expected from previous interpretations of the experimental temperature-depth profiles from GRT-1 and GRT-2 wells (Baujard et al. 2017). Previous studies suggest that the hydraulic cap rock should correspond to the top of the Muschelkalk formations at a depth of $1.65 \mathrm{~km}$. However, the hydraulic cap rock is obtained in the best model at a depth of $1.2 \mathrm{~km} \pm$ $0.1 \mathrm{~km}$ and is associated to a very good fit of the observed GRT-1 $T$-log. As illustrated in Fig. 3, the depth is close to the depth for the bottom of the Tertiary formations and not the depth of the transition between the sediments and the granitic basement. Interestingly, the bottom of the cap rock does not correspond to the breaking point of GRT-1 log located at the Muschelkalk top. Darcy's velocities in our model are of the same order of magnitude as the estimated values from previous numerical studies in the Upper Rhine Graben (Clauser 1990; Kohl 2000; Guillou-Frottier et al. 2013) and hydraulic tests (Bari et al. 1998). However, the Darcy's velocity is slightly higher than the one predicted in the Buntsandstein sandstone (between 1.8 and $2.2 \mathrm{~km}$ in depth) of the order of $5-10 \mathrm{~cm}_{\text {year }}{ }^{-1}$ by (Guillou-Frottier et al. 2013). This may be due to the high large-scale permeability found in the lower sediments and upper granites, higher than the one found for a similar model of Soultz-sous-Forêts (see Fig. 4). Figure 3 shows the variation of the vertical component of the surface heat flow along the $x$-axis in the model. The average surface heat flow is $128 \mathrm{~mW} \mathrm{~m} \mathrm{~m}^{-2} \pm 12 \mathrm{~mW} \mathrm{~m}^{-2}$. This value is in accordance with that found in the Upper Rhine Graben Region, $150 \mathrm{~mW} \mathrm{~m}^{-2}$ in Soultz-sous-Forêts (Bächler et al. 2003; Pribnow and Schellschmidt 2000; Clauser et al. 2002).

The range of laboratory values (as hatched zones), the prior distributions (as dashed lines) and the inverted properties (as thicked lines) are plotted in Fig. 4. The inverted permeabilities are, respectively, around $1.0 \times 10^{-16} \mathrm{~m}^{2}$ and $8.0 \times 10^{-16} \mathrm{~m}^{2}$ in the upper sediments (above $1.2 \mathrm{~km}$ of depth) and lower granites. The permeability is $1.6 \times 10^{-14}$ $\mathrm{m}^{2}$ in the lower sediments (below $1.2 \mathrm{~km}$ deep) and upper granites. The permeabilities are in good agreement with laboratory values. Concerning the thermal conductivities, they are, respectively, 1.4 and $3.1 \mathrm{~W} \mathrm{~m}^{-1} \mathrm{~K}^{-1}$ in the sediments and granites, which is also consistent with laboratory values.

Two cap rocks can be identified from the estimated vertical profiles of $K_{\text {int }}$ and $\lambda$. The hydraulical cap rock is associated at its base to the high contrast of permeability and the 


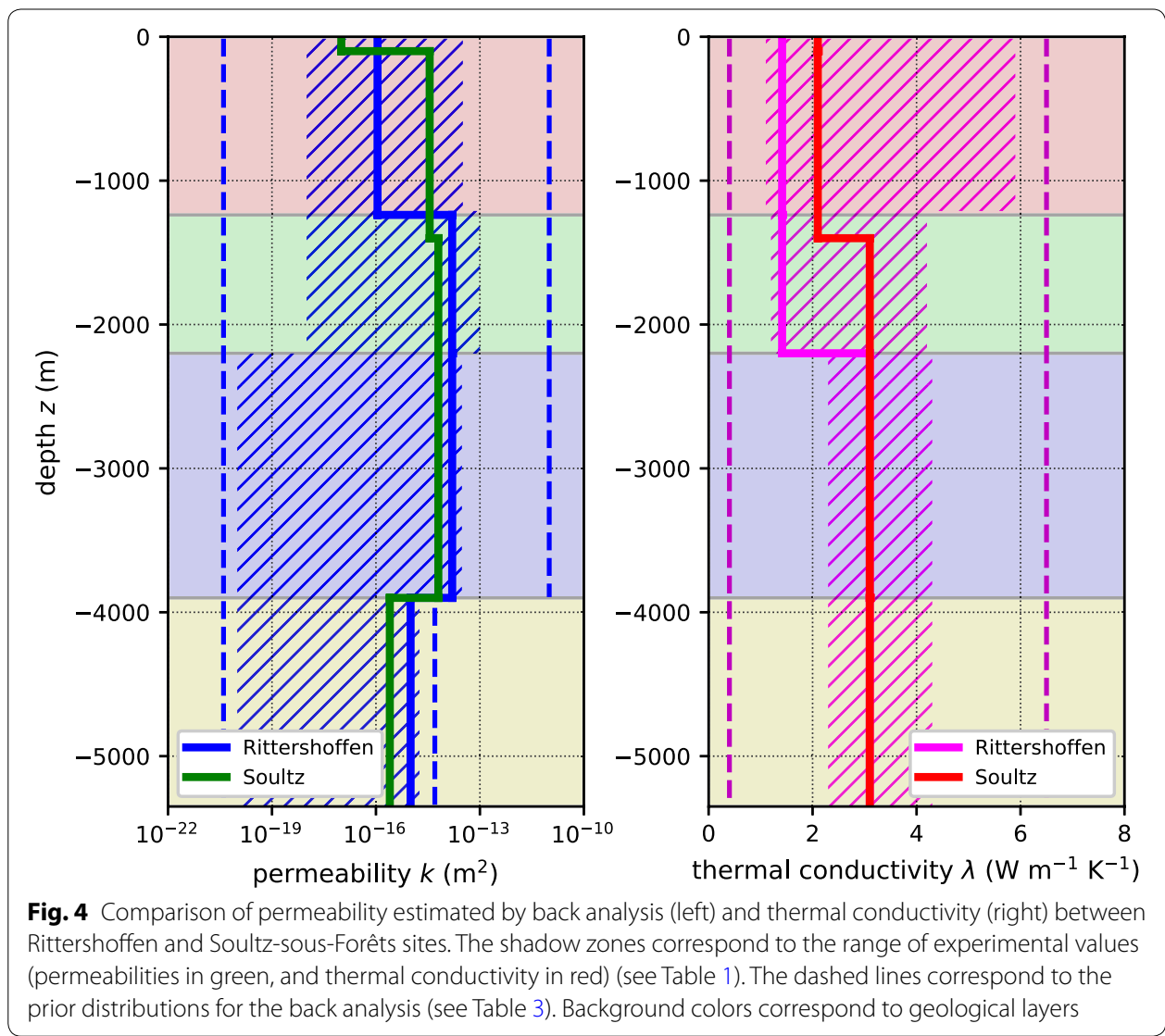

thermal cap rock to the discrepancy of thermal conductivity. Here, the bottom of the hydraulical cap rock (i.e., the top of the convection cells, see Fig. 3) is identified at the interface between the upper and lower sediments. The contrast of permeability is associated here with the high fracture density in the lower sediments and the granite compared to the upper sediments (Vidal et al. 2016b, 2017). The change of the rock property does not correspond to a contrast in terms of lithology. On the contrary, the contrast of thermal conductivity is located at the interface between the sediments and the granitic basement. The whole sedimentary cover associated with a lower thermal conductivity than in the basement contributes to a thermal blanketing of the insulating sediments. The effect has been already identified as a key factor to explain the higher geothermal gradient at depth than the average European one (Freymark et al. 2017; Scheck-Wenderoth et al. 2014). The discrepancy in terms of depths between the permeability and thermal conductivity contrast highlights a decoupling of the cap rocks: the whole sedimentary cover corresponds to the thermal cap rock, whereas only the upper sediments behave as a hydraulic cap rock.

In our computation, the regional Rittershoffen stress state is assumed to be similar to that of the Soultz site as proposed in Baujard et al. (2017). The observed trends of principal stress values with depth, established for the Soultz site (Evans et al. 2009), are then used for the Rittershoffen reservoir. They are presented in Appendix 2 as Eqs. 19, 20 and 21. To reproduce these observed trends of the stress state, a back analysis of the elastic 


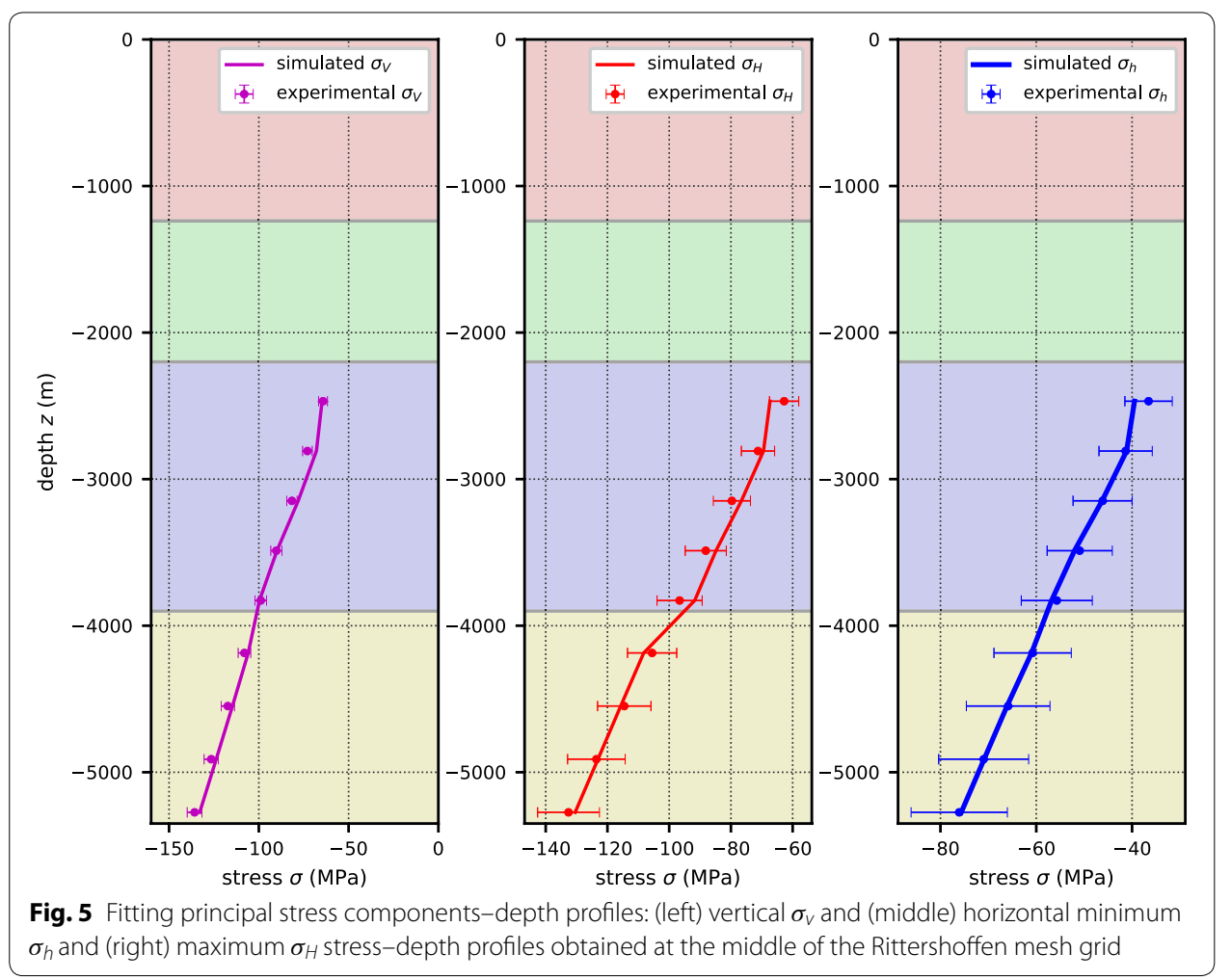

moduli (Young's modulus and Poisson's ratio) is performed. The model is assumed to be oriented along the direction of the maximum horizontal principal stress. Figure 5 presents the best fits by the simulated principal stress-depth profiles of the observed trends. The inverted Young's modulus and Poisson's ratio-depth profiles (as thick lines) are plotted in the new Fig. 6 . The range of laboratory values are plotted as hatched zones, and the prior distributions as dashed lines. The inverted Young's moduli are respectively 15 and $25 \mathrm{GPa}$ for the sediments and for the granites. The inverted Young's moduli are small compared to the laboratory values in particular for the granites. They are the longterm moduli, different from the short-term measurements at the laboratory scale. The inverted Poisson's ratio are, respectively, $0.23,0.25$ and 0.20 for the sediments, the upper and the lower granites, in accordance with experimental values.

\section{Discussion}

\section{Influence of the large-scale fault in the THM model}

In the present study, the hydrothermal circulation is assumed to be mainly driven by fractures and faults networks having a dimension less than the representative elementary volume (REV) with a size of $100 \mathrm{~m}$. The hypothesis is different from many Soultzsous-Forêts modeling studies, which consider that large-scale faults (i.e., larger than 100 $\mathrm{m})$ contribute dominantly to the thermal state and accordingly have to be included in the reservoir model (Baujard and Bruel 2006; Kohl and Mégel 2007; Kohl 2000).

To support our assumption, a large-scale fault has been included in our reservoir model. It corresponds to the Rittershoffen fault, a major fault zone with a north-south strike. It extends from the surface to $3.5 \mathrm{~km}$ deep (GeORG 2013), with a thickness of 


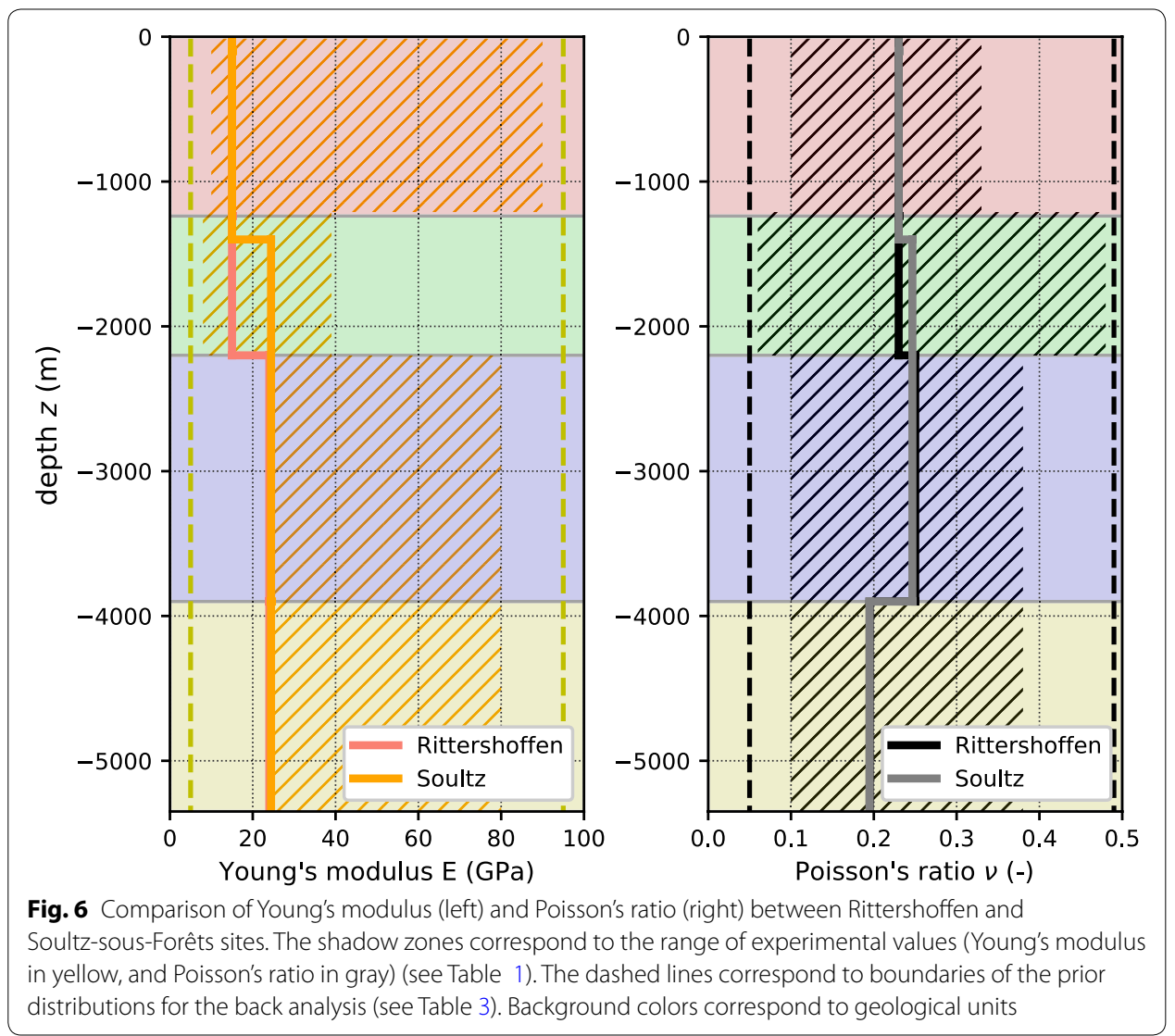

about $40 \mathrm{~m}$ (Baujard et al. 2016). The fault permeability has been estimated to be $5.34 \times 10^{-14} \mathrm{~m}^{2}$ (Baujard et al. 2017). Several values of fault dip have been estimated from different approaches: (i) $45^{\circ}$ from $3 \mathrm{D}$ geological model at reservoir scale based on seismic and log data (Baujard et al. 2017; ii) $74^{\circ}$ in a regional scale best fitting plane of the seismic cloud from induced seismicity (Lengliné et al. 2017; iii) $83^{\circ}$ from small-scale acoustic image logs (Vidal et al. 2016a). The difference between the estimates may be linked to the scale discrepancy between the three approaches: the structural model is built at the $5 \mathrm{~km}$ scale, whereas the acoustic logs are performed at the scale of $0.2 \mathrm{~m}$. Simulations have been carried out with the different estimated dips: $45^{\circ}, 74^{\circ}$ and $83^{\circ}$ to the west.

Figure 7 shows the comparison of the temperature-depth profiles between the cases with and without fault and Fig. 8 shows the stress-depth profiles. The maximum of temperature difference between the cases with and without the Rittershoffen fault is about $6{ }^{\circ} \mathrm{C}$ at $2.0 \mathrm{~km}$ deep. Temperatures are slightly higher in the sediments and weaker in the granite after adding the Rittershoffen fault. Differences in the fault dip have also negligible impact on the temperature distribution (less than $2{ }^{\circ} \mathrm{C}$ at $2.0 \mathrm{~km}$ in depth). Concerning the stress-depth profiles, the difference is even less noticeable (about $1 \mathrm{MPa}$ ) for the maximum horizontal stress at the transition between the upper and lower granites. All the stress-depth profiles still fit the experimental profiles of the three principal stress components with depth. Figure 9 shows the distribution of the Darcy's velocities in the 


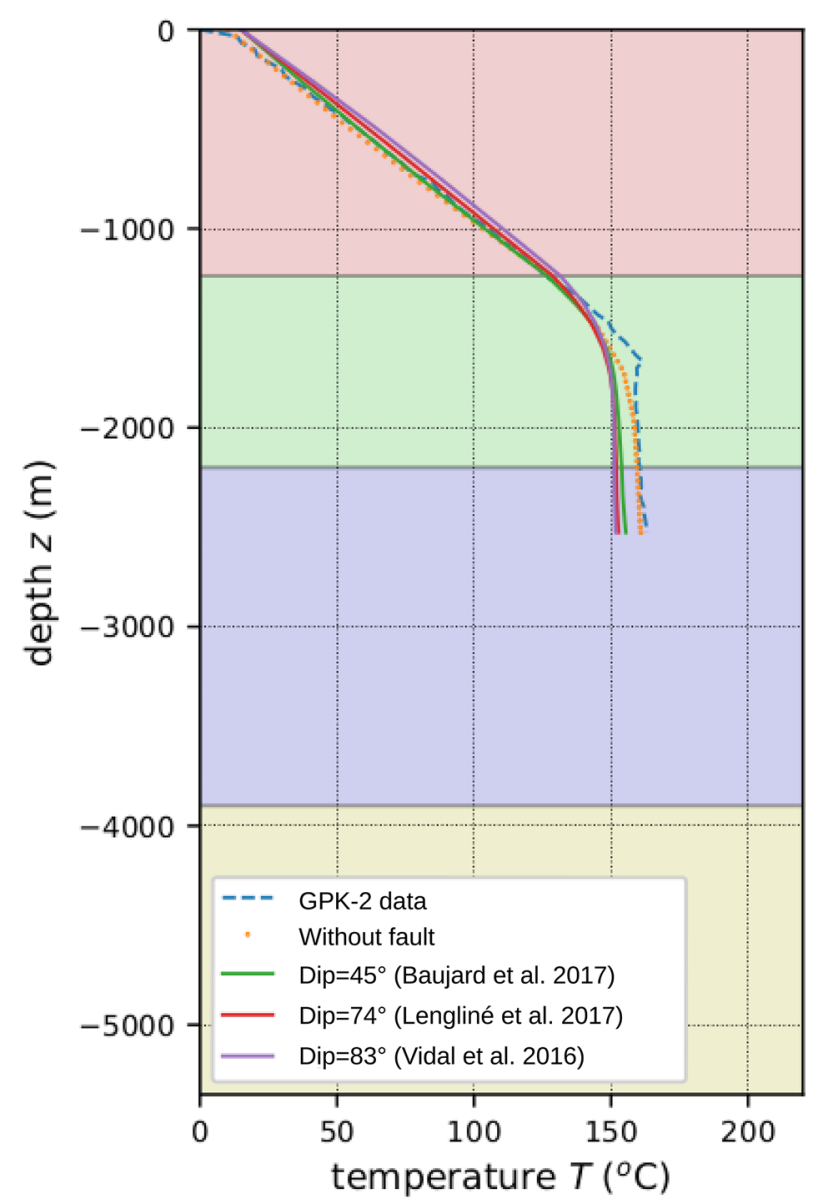

Fig. 7 Simulated temperature-depth profiles obtained at the maximum ascending flow profile from models including the Rittershoffen fault with different dips and compared to the model without fault

model including the fault with a dip of $45^{\circ}$. A circulation occurs upward along the fault with a maximum of Darcy's velocities of about $26.0 \mathrm{~cm} \mathrm{year}^{-1}$, slightly higher than in the case without fault. However, the system of convection cells stays undisturbed; their numbers and sizes are the same after inclusion of the fault. In conclusion, the simulations adding a large-scale fault in the model do not show an important influence on the simulated temperature and stress-depth profiles justifying the main assumption of our approach.

\section{Influence of the different couplings in the THM model}

The claim of a full thermo-hydro-mechanical analysis stands in our modeling approach by the inclusion of several coupling between the three physical processes. The material properties depend on field variables such as pressure, temperature and porosity (see Table 2). Concerning the poroelastic behavior of the system, the Cauchy stress is assumed to be split into two components with one being the hydraulic stress with its variation depending on one of the fluid pressures (see Eq. 8 in Appendix 1). The poroelasticity is also described by the incremental variation of porosity depending on the 


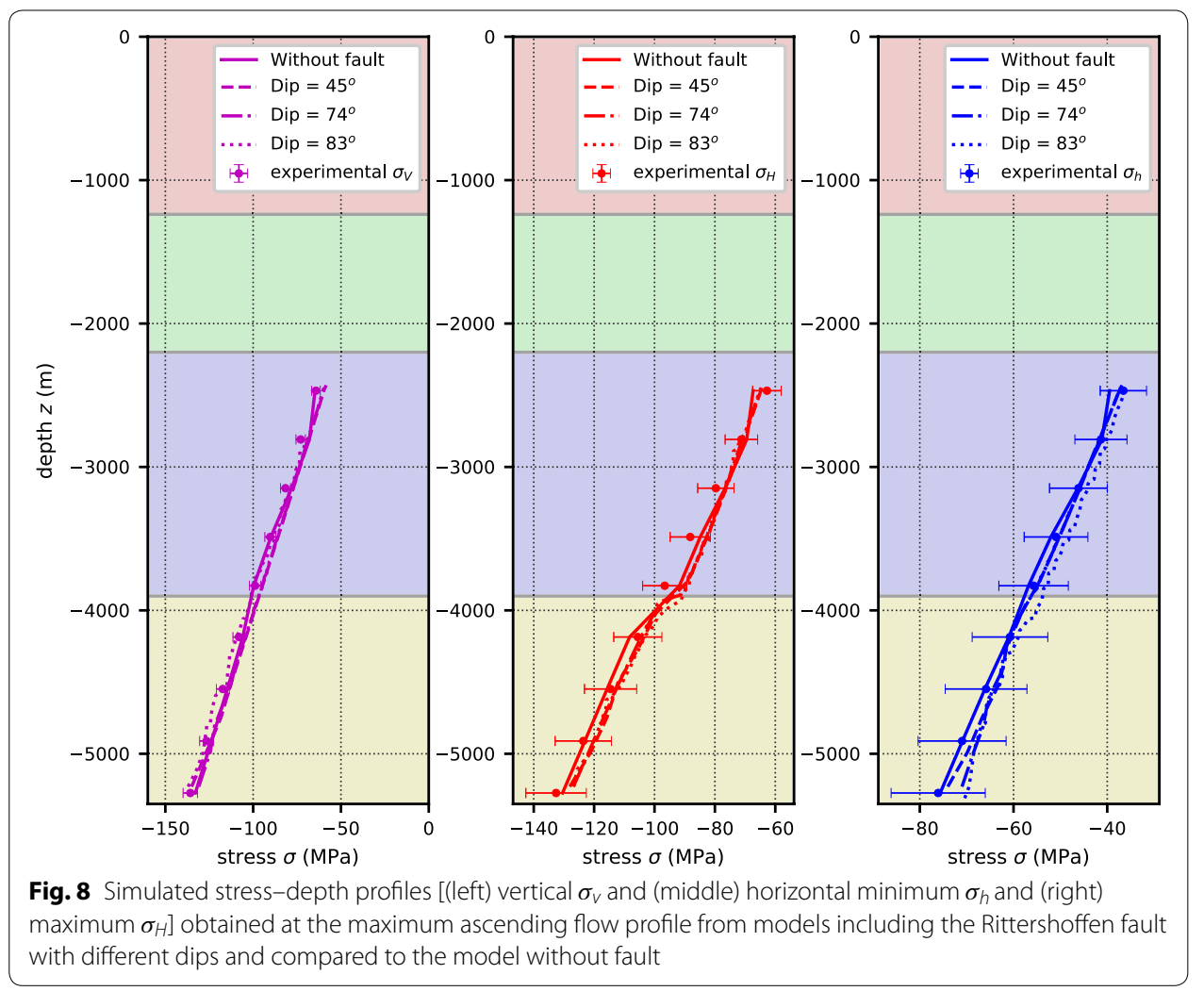

three generalized displacements: the temperature, the mechanical displacement and the fluid pressure (see Eq. 6 in Appendix 1).

To study the effect of the different couplings on the thermal state, simulations have been carried out after canceling them. Figure 10 shows the temperature-depth profiles and the associated maps of temperatures for these simulations. We can observe that the cancellation of the dependence of the thermics on the mechanical and hydraulic processes (HM) or of the hydraulics on the mechanics and thermics (TM) leads both to a large-scale diffusive case. The deactivation of the mechanical effect on the thermal and hydraulic processes $(\mathrm{TH})$ highlights a convection system, but different from the full THM model. It includes only two convective cells larger than the ones from the THM model and the reservoir temperature is slightly higher than in the previous model. To conclude, cancelling the mechanical or hydraulic parts of the THM model does have a clear impact on the thermal regime and the hydrothermal circulation.

\section{Comparison with the back analysis for the closeby Soultz-sous-Forêts site}

A two-dimensional THM model has been also developed for the Soultz-sous-Forêts site (Vallier et al. 2017). Permeabilities, thermal conductivities, Young's moduli and Poisson's ratios have been estimated to reproduce the GPK-2 temperature log and the total stress profiles via a similar back analysis. In Soultz, the best model highlights a hydrothermal circulation below a shallow bottom of the hydraulic cap rock at a depth of $100 \mathrm{~m}$, whereas it is at a depth of $1200 \mathrm{~m}$ in Rittershoffen. Figure 4 illustrates the estimated 


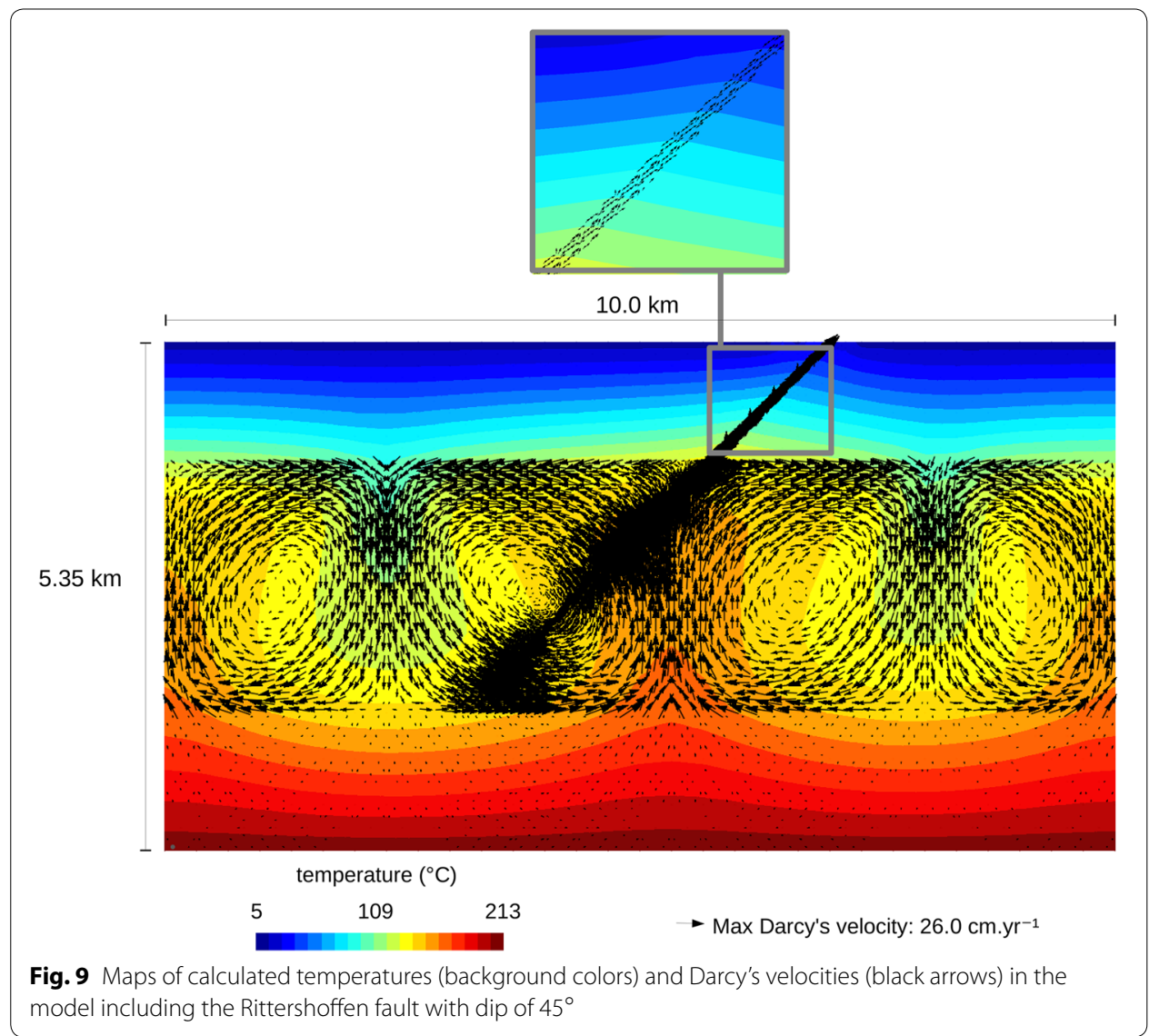

permeabilities and thermal conductivities-depth profiles for both Rittershoffen and Soultz-sous-Forêts sites.

In Soultz, the inverted permeabilities are, respectively, $1.0 \times 10^{-17} \mathrm{~m}^{2}, 3.5 \times 10^{-15} \mathrm{~m}^{2}$, $6.0 \times 10^{-15} \mathrm{~m}^{2}$ and $2.5 \times 10^{-16} \mathrm{~m}^{2}$ for the upper sediments, the lower sediments (below $100 \mathrm{~m}$ deep), the upper and the lower granites. The permeability increases with depth from the upper sediments to the lower sediments and upper granites. Importantly, the permeability of the lower sediments and the upper granite is very similar suggesting that the lithological transition between the sedimentary cover and the granitic basement is not significant for the hydraulic properties. The permeability decreases after $3.9 \mathrm{~km}$ in depth.

For the thermal conductivity in Soultz, the values are $3.1 \mathrm{Wm}^{-1} \mathrm{~K}^{-1}$ in the granites and $2.1 \mathrm{Wm}^{-1} \mathrm{~K}^{-1}$ in the sediments. The thermal conductivity increases at the interface between sediments and granitic basement. Then, its value remains constant in the whole granitic basement. The thermal property is controlled by the interface between the sediments and granites on the contrary to permeability.

Profiles for the two properties highlight that both geothermal sites share noticeable similarities. Inverted properties of the best models show common general trends and in particular, the decoupling of behaviors between the thermal and hydraulic cap rocks. Both sites show a blanketing effect from the whole sedimentary cover, whereas the top of the convective cells (i.e., the bottom of the hydraulic cap rock) is at the 


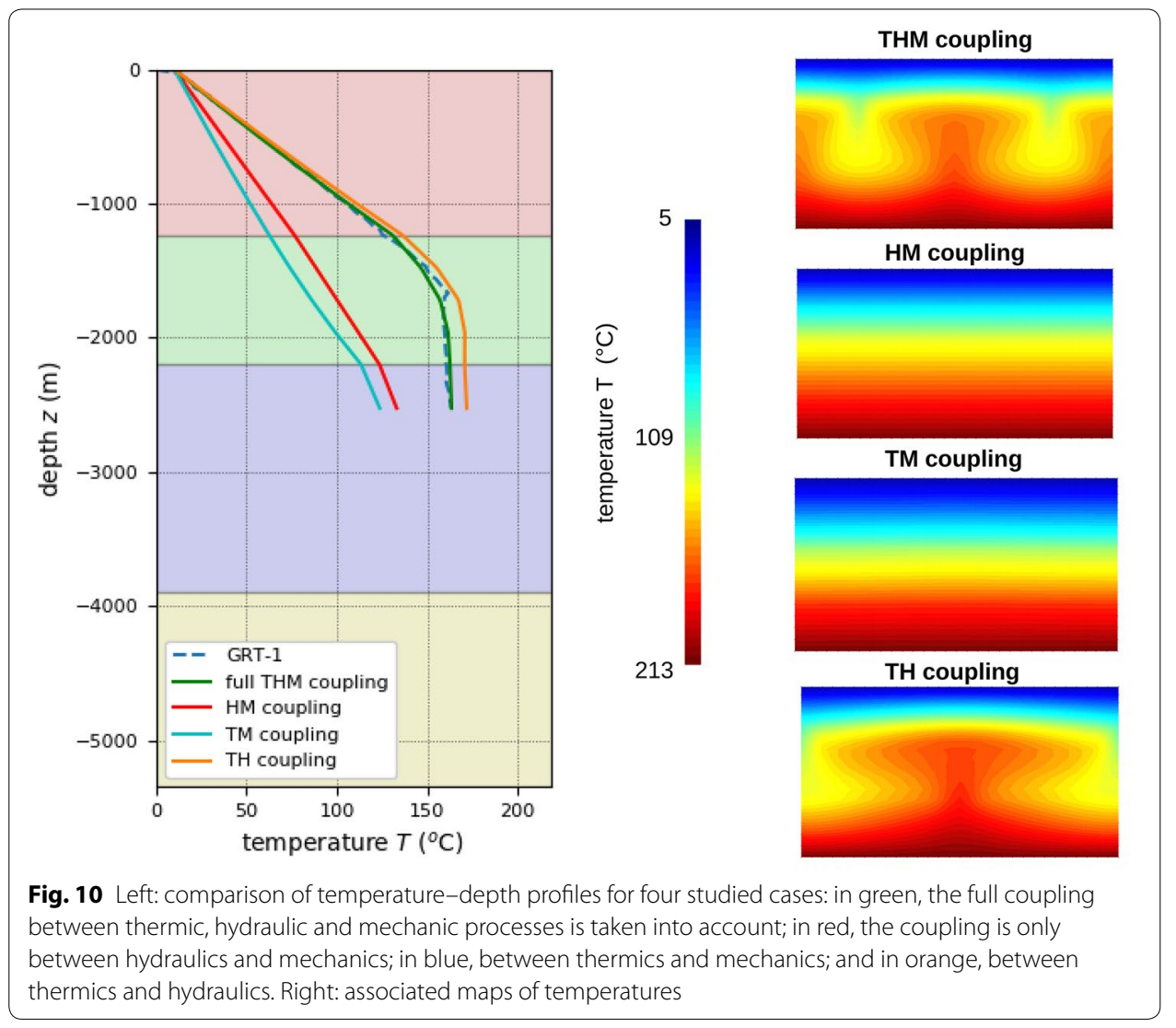

transition between the upper and lower sediments. The other similarity between both geothermal sites concerns the rock properties. The reservoir permeability is similar between both sites, about $1.0 \times 10^{-14} \mathrm{~m}^{2}$ in the granitic basement and the lower sediments. The permeability is also very close in the deep granites, about $6.0 \times 10^{-15} \mathrm{~m}^{2}$. The slightly higher permeability for the Rittershoffen reservoir can be explained by the more important fracture density in the granite compared to Soultz-sous-Forêts (Vidal et al. 2016b).

There is a noticeable discrepancy between the two sites: the thicknesses of the hydraulic cap rocks. The difference is more than $1 \mathrm{~km}$ and leads to a discrepancy between the permeabilities in the upper sediments. This difference can be explained by a higher fracture density for the sediments in Soultz-sous-Forêts than in Rittershoffen. This is consistent with the recent stratigraphic studies comparing the two geothermal sites (Aichholzer et al. 2016). Indeed, a more intense fault network has been observed for the sediments in Soultz-sous-Forêts (Aichholzer et al. 2016; Vidal et al. 2016a).

Figure 6 also provides a comparison of the estimated moduli for Rittershoffen and Soultz sites. The Young's modulus and Poisson's ratio are very similar in particular for the granitic basement between sites. 


\section{Comparison with the hydrothermal characterization of the GRT-1 and GRT-2 wells}

The study of (Baujard et al. 2017) analyzes the database obtained after stimulation and circulation testing of GRT-1 and GRT-2 wells in the Rittershoffen reservoir. In particular, a double porosity model area has been carried out with AQTESOLV software (Baujard et al. 2016) from the hydraulic data of the pumping tests. The reservoir thickness is assumed to be about $500 \mathrm{~m}$ and the model includes a fracture area $40 \mathrm{~m}$ thick. We aim to compare the results from our modeling approach with their interpretations of production and circulation tests.

Fracture and matrix permeabilities of, respectively, $5.34 \times 10^{-14} \mathrm{~m}^{2}$ and $9.2 \times 10^{-15}$ $\mathrm{m}^{2}$ have been evaluated from interpretations of GRT-2 hydraulic testing (Baujard et al. 2017). In our model, the computed permeability for the convective area (i.e., the lower sediments and the upper granites) is about $1.6 \times 10^{-14} \mathrm{~m}^{2}$. This value is between the matrix and fracture permeabilities proposed by Baujard et al. (2017). Our inverted permeability is then consistent with the values from the interpretations of hydraulic tests.

Baujard et al. (2017) proposed that the depth of the top of the Muschelkalk formations, i.e., $1.65 \mathrm{~km}$, is the depth of the hydraulic cap rock owing to the transition in the temperature log. In our study, the depth of the hydraulic cap rock has been evaluated at 1.2 $\mathrm{km} \pm 0.1 \mathrm{~km}$ after our back analysis, which is significantly above the important change of the temperature gradient. From the interpretation of temperature logs, the height of the convection cells is $1350 \mathrm{~m}$ (Baujard et al. 2017). In our model, the simulated convection cells have a height of $2.7 \mathrm{~km}$. They extend shallower into the sediments and much deeper into the granitic basement until $3.9 \mathrm{~km}$ in depth assuming that the deep granites in Rittershoffen are similar to the ones from the Soultz-sous-Forêts site.

Baujard et al. (2017) has also evaluated the Rayleigh number at Rittershoffen. This calculation aims to confirm that a hydrothermal convection occurs inside the Rittershoffen reservoir. The Rayleigh number is found to be included between 11.1 and 535.7. By using the same definition of the Rayleigh number (Desaive 2002; Turcotte 2014), we found a value of 50. Interestingly our value is included in the range found by Baujard et al. (2017). Knowing that the critical Rayleigh number is about 39.5 (Turcotte 2014), it confirms that a spontaneous convection inside the fractured granite is expected in the Rittershoffen model (Murphy 1979).

\section{Temperature lateral variability}

In the prospect of future geothermal exploitation, a precise assessment of the reservoir temperature at depth is required from measurements acquired on the near surface. To address the issue, we aim to bring some insights concerning the link between the lateral variability of the reservoir temperature at $2000 \mathrm{~m}$ depth and the one of the geothermal gradient obtained at the near surface.

Figure 11 shows different temperature-depth profiles taken at several horizontal positions (every kilometer). Measured T-logs GRT-1 and GPK-2 have been added for comparison. The lateral variability of the reservoir temperature at $2000 \mathrm{~m}$ deep is about $40-50{ }^{\circ} \mathrm{C}$. To be noted, the variability of the temperature-depth profiles in the Rittershoffen large-scale model is not enough to reproduce the GPK-2 temperature-depth 


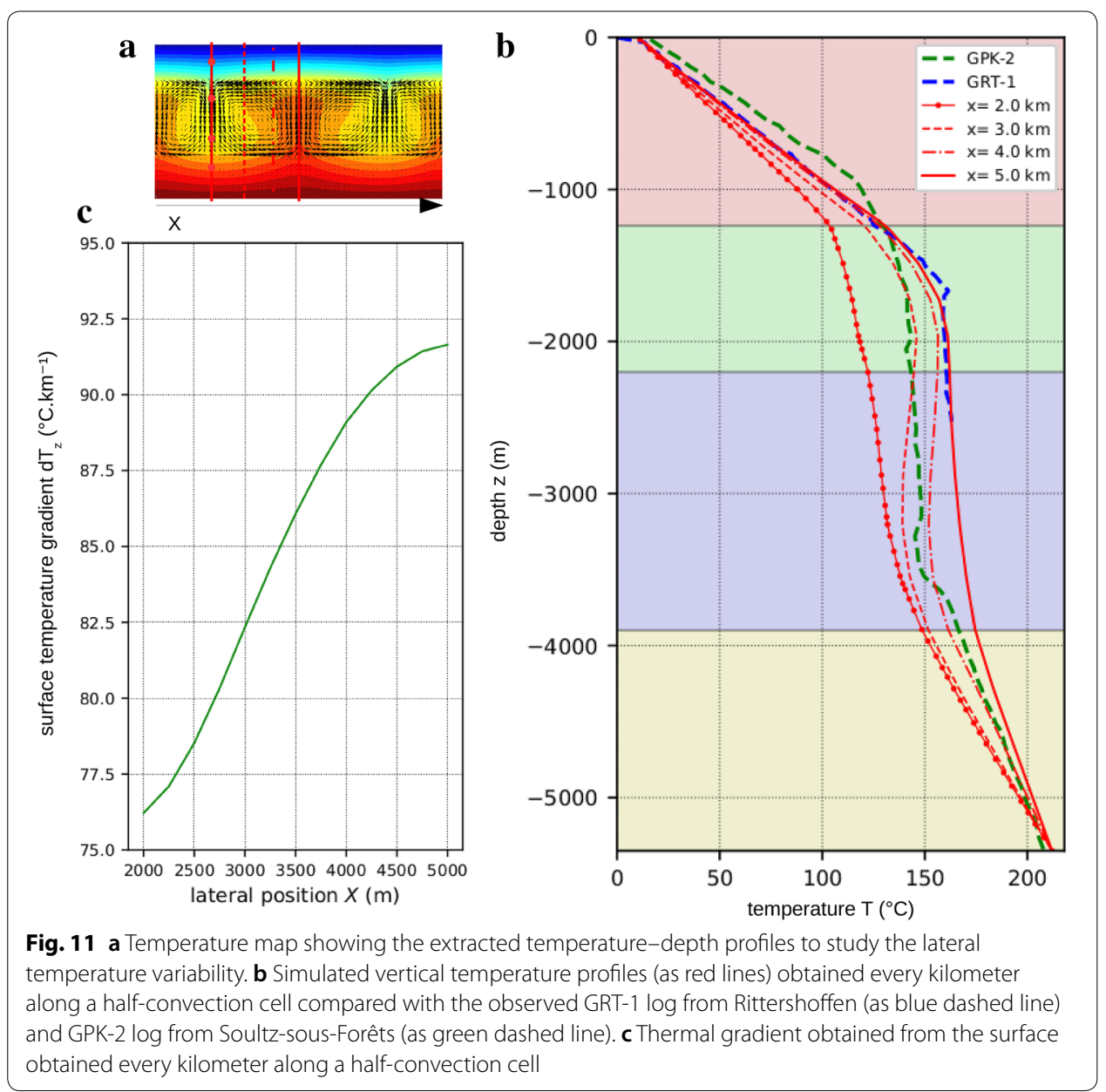

profile observed at the Soultz-sous-Forêts site even if both geothermal sites share similarities in terms of rock properties.

To better understand the link between the lateral variabilities of the reservoir temperature and the geothermal gradient, Fig. 11 illustrates also the variation of geothermal gradient at the near surface (for the first $200 \mathrm{~m}$ depth) along the $x$-axis. The thermal gradient varies between 76 and $91{ }^{\circ} \mathrm{C} \mathrm{km}^{-1}$. The same periodicity of $6 \mathrm{~km}$ is observed for both the geothermal gradient and the reservoir temperature. Interestingly, this periodicity of $6 \mathrm{~km}$ can be compared to the distance between Soultz-sous-Forêts and Rittershoffen sites (around $6.5 \mathrm{~km}$ ).

\section{Conclusion}

By using a back analysis confronting a THM model to the temperature and stress profiles observed at Rittershoffen, an excellent fit of the T-log has been found as well for the regional stress-depth trends. The bottom of the hydraulic cap rock (i.e., the top of the convection cells where a contrast of permeability is obtained) is identified at a depth of $1.2 \mathrm{~km} \pm 0.1 \mathrm{~km}$. This depth is close to the bottom of the Tertiary formations and does not correspond to the discontinuity of temperature-depth profile observed in the GRT-1 T-log at $1.65 \mathrm{~km}$ deep. The computed permeability is $1.6 \times 10^{-14} \mathrm{~m}^{2}$ for the 
lower sediments and the upper granite. This highlights that the lithological transition between the sediments and the granitic basement has little influence on the hydraulic property. Contrary to the hydraulic cap rock, the bottom of the thermal cap rock (i.e., the zone of thermal conductivity contrast) occurs at the interface between the sediments and the granite. The thermal conductivity is, respectively, 1.4 and $3.1 \mathrm{~W} \mathrm{~m}^{-1} \mathrm{~K}^{-1}$ in the sediments and granites. This means that the whole sedimentary cover contributes to a blanketing effect and that the thermal and hydraulical cap rocks are decoupled. The large-scale permeabilities, thermal conductivities and elastic moduli are mostly consistent with the values observed at the laboratory scale. They have been compared to the ones obtained from a similar back analysis at the closeby Soultz geothermal site. The permeability, thermal conductivity, Young's modulus and Poisson's ratio have the same general trend with depth and similar values at Soultz and Rittershoffen. Both sites highlight the same decoupling of the hydraulic and thermal cap rocks. The lateral variability of the reservoir temperature at $2.0 \mathrm{~km}$ deep is similar between Rittershoffen and Soultzsous-Forêts around $40-50{ }^{\circ} \mathrm{C}$. The same lateral periodicity of $6 \mathrm{~km}$ has been found for the geothermal gradient obtained from the near surface and the reservoir temperature. This might lead potentially to a promising tool to assess future geothermal resources. Moreover, further works are currently being done to investigate the potential influence of major faults in the model (e.g., here the Rittershoffen fault). This will allow us to better understand their influence on both thermal and mechanical behaviors inside the reservoir.

Authors' contributions

BV wrote the first version of the paper. The three other authors contributed to the final version of the manuscript. All authors read and approved the final manuscript.

Author details

'EOST-IPGS, University of Strasbourg/CNRS, 5, Rue René Descartes, Strasbourg, France. ${ }^{2}$ ICube Laboratory, UMR CNRS 7357, 72, Route du Rhin, 67411 IIIkirch, France.

\section{Acknowledgements}

The present work has been done under the framework of the LABEX ANR-11-LABX-0050-G-EAU-THERMIE-PROFONDE and benefits from a state funding managed by the French National Research Agency (ANR) as part of the "Investments for the Future" program. It has also been funded by the EGS Alsace Grant from ADEME. The authors would like to thank Christoph Clauser, Albert Genter, Clément Baujard, Thomas Kohl, Chrystel Dezayes, David Bruhn, Nima Gholizadeh Doonechaly, Bernard Sanjuan, Benoit Valley, Judith Sausse, Philippe Jousset, Dominique Bruel, Eva Schill, Patrick Baud, Mike Heap, Luke Griffiths, Alexandra Kushnir, Olivier Lenglinè, Coralie Aichholzer, Philippe Duringer and François Cornet for very fruitful discussions. We thank also the anonymous reviewers and the editorial team for their comments.

Competing interests

The authors declare that they have no competing interests.

\section{Appendices}

\section{Appendix 1: Equations of thermo-poro-elastic behavior}

We adopt here the following notations: $T$ is the temperature $[\mathrm{K}], p_{w}$ the pore pressure $[\mathrm{Pa}]$, $\phi$ the Eulerian porosity, $\epsilon$ the linearized strain tensor, $\mathbf{F}^{\mathrm{m}}$ the massic body force $\left[\mathrm{N} \mathrm{kg}^{-3}\right]$, $r$ the homogenized specific mass $\left[\mathrm{kg} \mathrm{m}^{-3}\right], m_{w}$ the brine mass content $\left[\mathrm{kg} \mathrm{m}^{-3}\right], \mathbf{M}_{w}$ the water surface mass flow $\left[\mathrm{kg} \mathrm{m}^{-2} \mathrm{~s}^{-1}\right], \theta_{\text {rad }}$ the heat source due to the radioactivity of rocks [W m$\left.{ }^{-3}\right], h_{w}^{m}$ the fluid specific enthalpy $\left[\mathrm{J} \mathrm{kg}^{-1}\right], Q$ the rate of internal energy neither resulting from convection nor conduction $\left[\mathrm{J} \mathrm{m}^{-3}\right]$, $\mathbf{q}$ the heat conductive flow $\left[\mathrm{J} \mathrm{m}^{-2} \mathrm{~s}^{-1}\right], \sigma$ the Cauchy stress tensor $[\mathrm{Pa}], \sigma^{\prime}$ its effective counterpart, $\sigma_{p}$ the hydraulic stress, $\mathbb{C}$ the drained elasticity tensor $[\mathrm{Pa}], \mathbf{1}$ the unit tensor, $\alpha_{0}$ the linear thermal dilation of the dry material 
$\left[\mathrm{K}^{-1}\right], \lambda$ the thermal conductivity $\left[\mathrm{W} \mathrm{m}{ }^{-1} \mathrm{~K}^{-1}\right], K_{\text {int }}$ the intrinsic permeability $\left[\mathrm{m}^{2}\right], \mu_{w}$ the fluid dynamic viscosity $[\mathrm{Pa} \mathrm{s}]$ and $\rho_{w}$ the fluid density $\left[\mathrm{kg} \mathrm{m}^{-3}\right]$. The balance equations correspond to the mechanical equilibrium, brine mass and energy balance:

$$
\begin{aligned}
& \nabla \cdot \sigma+r \mathbf{F}^{\mathbf{m}}=0, \\
& \frac{\partial m_{w}}{\partial t}+\nabla \cdot \mathbf{M}_{w}=0, \\
& \mathbf{M}_{w} \cdot \mathbf{F}^{\mathbf{m}}+\theta_{\text {rad }}=\frac{\partial Q}{\partial t}+\nabla \cdot\left(h_{w}^{m} \mathbf{M}_{w}\right)+\nabla \cdot \mathbf{q}+h_{w}^{m} \frac{\partial m_{w}}{\partial t} .
\end{aligned}
$$

The poro-elastic behavior is governed by the following relations:

$$
\begin{aligned}
& \sigma=\sigma^{\prime}+\sigma_{p} \mathbf{1}, \\
& \mathrm{d} \sigma_{p}=-b \mathrm{~d} p_{w}, \\
& \mathrm{~d} \phi=(b-\phi)\left(\mathrm{d} \epsilon_{v}-3 \alpha_{0} \mathrm{~d} T+\frac{\mathrm{d} p_{w}}{K_{s}}\right), \\
& m_{w}=\phi\left(1+\epsilon_{v}\right) \rho_{w}-\phi_{0} \rho_{w}^{0}
\end{aligned}
$$

with $\epsilon_{v}=\operatorname{Tr}(\epsilon)$ the total volume strain, $K_{s}$ the matrix bulk modulus [Pa], $b$ the Biot coefficient, $\rho_{w}^{0}$ the initial fluid density $\left[\mathrm{kg} \mathrm{m}^{-3}\right]$ and $\phi_{0}$ the initial porosity. The thermodynamic flows $\sigma, \mathbf{M}_{w}$, and $\mathbf{q}$ are linearly linked to forces $\epsilon, \nabla p_{w}, \nabla T$ according to:

$$
\begin{aligned}
& \mathrm{d} \sigma=\mathbb{C}:\left(\mathrm{d} \epsilon-\alpha_{0} \mathrm{~d} T \mathbf{1}\right) \\
& \mathbf{M}_{w}=\frac{\rho_{w} K_{i n t}}{\mu_{w}}\left(-\nabla p_{w}+\rho_{w} \mathbf{F}^{\mathbf{m}}\right) \\
& \mathbf{q}=-\lambda \nabla T, \\
& \frac{\partial Q}{\partial t}=3 \alpha_{0} K_{0} T \frac{\partial \epsilon}{\partial t}-3\left[(b-\phi) \alpha_{0}+\alpha_{w} \phi\right] T \frac{\partial p_{w}}{\partial t}+\left(c_{s}-9 T K_{0} \alpha_{0}^{2}\right) \frac{\partial T}{\partial t}
\end{aligned}
$$

with $K_{0}$ the bulk modulus of the skeleton and $c_{s}$ the specific heat at constant stress. Note that $\rho_{w}$ and $\mu_{w}$ as well as $\lambda$ and $c_{s}$ are functions of temperature and or pore pressure. Concerning Fourier's law, the thermal conductivity of the dry rock is described by the classical mixing law:

$$
\lambda_{\mathrm{dry}}(T)=\left(1-\phi_{0}\right) \lambda_{\mathrm{s}}(T)+\phi_{0} \lambda_{\text {air }}(T)
$$

with $\lambda_{\mathrm{s}}$ (resp. $\lambda_{\text {air }}$ ) the thermal conductivity of solid grains (resp. air). We assume that the thermal conductivity of air is negligible. Consequently, the thermal conductivity of solid grains can be written as:

$$
\lambda_{\mathrm{s}}(T)=\frac{\lambda_{\mathrm{dry}}(T)}{1-\phi_{0}} .
$$


Thermal conductivity of the dry material is assumed to depend linearly on temperature:

$$
\lambda_{\mathrm{dry}}(T)=a_{\lambda_{\mathrm{dry}}}+b_{\lambda_{\mathrm{dry}}} T
$$

with $a_{\lambda_{\text {dry }}}$ and $b_{\lambda_{\text {dry }}}$ empirical constant parameters obtained from experimental measurements. Finally, the homogenized thermal conductivity of the saturated porous media is expressed by using the same kind of mixing law as previously:

$$
\lambda(T)=(1-\phi) \lambda_{\mathrm{dry}}(T)+\phi \lambda_{w}(T) .
$$

The specific heat for the dry medium is defined using a similar experimental correlation as Eq. (14):

$$
c_{\mathrm{dry}}(T)=a_{c_{\mathrm{dry}}}+b_{c_{\mathrm{dry}}} T .
$$

As proposed for the homogenized thermal conductivity, we can define the specific heat capacity and the initial specific mass as:

$$
\begin{aligned}
& c_{s}(T)=\frac{c_{\mathrm{dry}}(T)-\phi_{0} c_{\mathrm{air}}}{1-\phi_{0}} \\
& r_{0}=\rho_{\mathrm{dry}}+\phi_{0} \rho_{w}^{0}
\end{aligned}
$$

with $c_{\text {air }}$ the specific heat capacity of air.

\section{Appendix 2: Observed trends of the three principal stress magnitudes with depth}

Here, the stress state is assumed to be the same as in the Soultz-sous-Forêts geothermal site (Baujard et al. 2017). Studies of the stress state at Soultz-sous-Forêts have been performed from BoreHole TeleViewer (BHTV) images, gamma density logs, distribution and magnitude of breakouts. In particular, the technical report Evans et al. (2009) describes as relations the profiles of the three principal stress magnitudes with depth:

$$
\begin{aligned}
& \sigma_{\nu}=(-30 \pm 0.60)+(25.50 \pm 0.98) z, \\
& \sigma_{h}=(-1.78 \pm 1.82)+(14.09 \pm 0.45) z, \\
& \sigma_{H}=(-1.30 \pm 0.10)+(24.90 \pm 1.88) z,
\end{aligned}
$$

with $z$ expressed in $\mathrm{km}$ and all stresses in MPa.

\section{Publisher's Note}

Springer Nature remains neutral with regard to jurisdictional claims in published maps and institutional affiliations.

Received: 16 April 2018 Accepted: 17 October 2018

Published online: 02 November 2018

\footnotetext{
References

Aichholzer C, Duringer P, Orciani S, Genter A. New stratigraphic interpretation of the Soultz-sous-Forêts 30-year-old geothermal wells calibrated on the recent one from Rittershoffen (Upper Rhine Graben, France). Geothermal Energy. 2016;4(1):13.

Baillieux P, Schill E, Edel J-B, Mauri G. Localization of temperature anomalies in the upper rhine graben: insights from geophysics and neotectonic activity. Int Geol Rev. 2013;55(14):1744-62.
} 
Baria R, Baumgärtner J, Gérard A, Jung R. The European HDR programme 1992-1995. Technical report, Joule III Programme, final report EUR 18925 EN. 1998.

Baujard C, Bruel D. Numerical study of the impact of fluid density on the pressure distribution and stimulated volume in the Soultz HDR reservoir. Geothermics. 2006;35(5):607-21.

Baujard C, Genter A, Graff J.J, Maurer V, Dalmais E. ECOGl a new deep EGS project in Alsace, Rhine Graben, France In: Proceedings world geothermal congress. 2015.

Baujard C, Genter A, Dalmais E, Maurer V, Hehn R, Rosillette R. Temperature and hydraulic properties of the Rittershoffen EGS reservoir, France In: European geothermal congress. 2016.

Baujard C, Genter A, Dalmais E, Maurer V, Hehn R, Rosillette R, Vidal J, Schmittbuhl J. Hydrothermal characterization of wells GRT-1 and GRT-2 in Rittershoffen, France: implications on the understanding of natural flow systems in the rhine graben. Geothermics. 2017;65:255-68.

Bachler D, Kohl T. Coupled thermal hydraulic chemical modelling of enhanced geothermal systems. Geophys I Int. 2005;161(2):533-48.

Bächler D, Kohl T, Rybach L. Impact of graben-parallel faults in hydrothermal convection—Rhine Graben case study. Phys Chem Earth. 2003;28(1):431-41.

Bär K. Untersuchung der tiefengeothermischen Potenziale von Hessen. PhD thesis, Technische Universität, Darmstadt. 2012.

Cacas M, Ledoux E, de Marsily G, Tillie B, Barbreau A, Durand E, Feuga B, Peaudecerf P. Modeling fracture flow with a stochastic discrete fracture network: Calibration 1. The flow and validation model. Water Resour Res. 1990;27:479-89.

Clauser C, Villinger H. Analysis of conductive and convective heat transfer in a sedimentary basin, demonstrated for the Rheingraben. Geophys J Int. 1990;100(3):393-414.

Clauser C, Griesshaber E, Neugebauer HJ. Decoupled thermal and mantle helium anomalies: implications for the transport regime in continentl rift zones. J Geophysi Res. 2002;7:10.

Cornet FH, Bérard T, Bourouis S. How close to failure is a granite rock mass at a $5 \mathrm{~km}$ depth? Int J Rock Mech Mining Sci. 2007:44(1):47-66.

Coussy O. Poromechanics. Chihester: Wiley; 2004.

Desaive T. Thermoconvection dans les milieux poreux: stabilite et dynamique non-lineaire. PhD thesis, Université de Liège. Facultés Sciences Appliquées. 2002.

Dezayes C, Gentier S, Genter A. Deep geothermal energy in Western Europe: the Soultz project. Orleans: Technical Report; 2005a.

Dezayes C, Chevremont P, Tourlière B, Homeier G.A G. Geological study of the GPK4 HFR borehole and correlation with the GPK3 borehole (Soultz-sous-Forêts, France). brgm/rp-53697-fr. Technical report, BRGM. 2005b.

Dezayes C, Valley B, Maqua E, Syren G, Genter A. Natural fracture system of the Soultz granite based on UBI data in the GPK3 and GPK4 wells. In: Proceedings of the EHDRA scientific conference, Soultz-sous-Forêts France. 2005c. p. 9.

Dezayes C, Sanjuan B, Gal F, Lerouge C, Fluid geochemistry monitoring and fractured zones characterization in the GRT1 borehole (ECOGI project, Rittershoffen, Alsace, France). In: Deep Geothermal Days, Paris, France. 2014.

Dezayes C, Genter A, Valley B. Structure of the low permeable naturally fractured geothermal reservoir at Soultz. Comptes Rendus Geosci. 2010;342(7):517-30.

Diersch HJG, Kolditz O. Coupled groundwater flow and transport: 2. Thermohaline and $3 \mathrm{~d}$ convection systems. Adv Water Resour. 1998:21(5):401-25.

Doherty J. Model independent parameter estimation. 2005. http://www.pesthomepage.org.

EDF R. Code \_Aster Open Source—general FEA software. 2016. http://www.code-aster.org.

Evans K, Valley B, Häring M, Hopkirk R, Baujard C, Kohl T, Magel T, André L, Portier S, Vuataz F. Studies and support for the EGS reservoirs at Soultz-sous-Forêts. Centre for Geothermal Research CREGE CHYN: Technical report; 2009.

Freymark J, Sippel J, Scheck-Wenderoth M, Bar K, Stiller M, Fritsche J-G, Kracht M. The deep thermal field of the Upper Rhine Graben. Tectonophysics. 2017:694(1):114

Gaucher E, Maurer V, Wodling H, Grunberg M. Towards a dense passive seismic network over Rittershoffen geothermal field In: 2nd European geothermal workshop, France. 2013.

Gelet R, Loret B, Khalili N. A thermo-hydro-mechanical coupled model in local thermal non-equilibrium for fractured HDR reservoir with double porosity. J Geophys Res. 2012;B7:117.

Genter A, Evans K, Cuenot N, Fritsch D, Sanjuan B. Contribution of the exploration of deep crystalline fractured reservoir of Soultz to the knowledge of enhanced geothermal systems (EGS). Comptes Rendus Geosci. 2010;342(7):502-16.

Genter A, Cuenot N, Graff JJ, Schmittbuhl J, Villadangos G. La géothermie profonde en France: quelles leçons tirer du projet pilote de Soultz-sous-Forêts pour la réalisation dun projet industriel à Rittershoffen. Revue Géologues. 2015;185:97-101.

Genter A, Baujard C, Cuenot N, Dezayes C, Kohl T, Masson F, Sanjuan B, Scheiber J, Schill E, Schmittbuhl J. Geology, geophysics and geochemistry in the Upper Rhine Graben: the frame for geothermal energy use. In: European Geothermal Congress. 2016.

GeORG Potentiel géologique profond du Fossé Rhénan supérieur. Parties 1 à 4. 2013. http://www.geopotenziale.eu.

Gérard A, Genter A, Kohl T, Lutz P, Rose P, Rummel F. The deep EGS (enhanced geothermal system) project at Soultz-sousForêts (Alsace, France). Geothermics. 2006;35(4):473-83.

Griffiths L, Heap M, Wang F, Daval D, Gilg H, Baud P, Schmittbuhl J, Genter A. Geothermal implications for fracture-filling hydrothermal precipitation. Geothermics. 2016;64:235-45.

Guillou-Frottier L, Carre C, Bourgine B, Bouchot V, Genter A. Structure of hydrothermal convection in the Upper Rhine Graben as inferred from corrected temperature data and basin scale numerical models. JVolcanol Geotherm Res. 2013:256:29-49.

Haas IO, Hoffmann CR. Temperature gradient in Pechelbronn oil-bearing region, Lower Alsace: its determination and relation to oil reserves. AAPG Bull. 1929;13(10):1257-73.

Haenel R. Plateau Uplift. Geothermal investigations in the Rhenish Massif. Berlin: Springer; 1983. p. 228-46. 
Heap M, Kushnir A, Gilg A, Wadsworth F, Reuschlè T, Baud P. Microstructural and petrophysical properties of the permotriassic sandstones (Buntsandstein) from the Soultz-sous-Forêts geothermal site (France). Geotherm Energy. 2017;5(1):26.

Hehn R, Genter A, Vidal J, Baujard C. Stress field rotation in the EGS well GRT-1 (Rittershoffen, France) In: European Geothermal Congress. 2016.

Hettkamp T, Fuhrmann G, Rummel F. Hydraulic properties in the rhine graben basement material. Bull Hydrogéol. 1999:17:143-50.

Huenges E, Ledru P. Geothermal energy systems: exploration, development, and utilization. Hoboken: Wiley; 2011.

Jain C, Vogt C, Clauser C. Maximum potential for geothermal power in germany based on engineered geothermal systems. Geothermal Energy. 2015;3(1):15.

Kestin J, Khalifa HE, Correia RJ. Tables of the dynamic and kinematic viscosity of aqueous $\mathrm{NaCl}$ solutions in the temperature range $20-150^{\circ} \mathrm{C}$ and the pressure range $0.1-35 \mathrm{MPa}$. J Phys Chem Ref Data. 1981;10(1):71-88.

Kirk SS, Williamson DM. Structure and thermal properties of porous geological materials. AIP Conference Proc. 2012;1426:867-70.

Kohl T, Mégel T. Predictive modeling of reservoir response to hydraulic stimulations at the European EGS site Soultz-sousForêts. Int J Rock Mech Mining Sci. 2007;44(8):1118-31.

Kohl T, Bächler D, Rybach L. Steps towards a comprehensive thermo-hydraulic analysis of the HDR test site Soultz-sousForêts In: Proceedings world geothermal congress. 2000. p. 2671-6.

Kohl T, Evansi KF, Hopkirk RJ, Rybach L. Coupled hydraulic, thermal and mechanical considerations for the simulation of hot dry rock reservoirs. Geothermics. 1995;24(3):345-59.

Kolditz O, Clauser C. Numerical simulation of flow and heat transfer in fractured crystalline rocks: application to the hot dry rock site in Rosemanowes (UK). Geothermics. 1998;27(1):1-23.

Kosack C, Vogt C, Clauser CVR. Stochastic permeability estimation for Soultz-sous-Forêts EGS reservoir In: Thirty-sixth workshop on geothermal reservoir engineering stanford university, United-States. 2011. p. 1-9.

Lengliné O, Boubacar M, Schmittbuhl J. Seismicity related to the hydraulic stimulation of GRT1, Rittershoffen, France. Geophys J Int. 2017;208(1):1704-15. https://doi.org/10.1093/gji/ggw490.

Magnenet V, Fond C, Genter A, Schmittbuhl J. Two-dimensional THM modelling of the large scale natural hydrothermal circulation at Soultz-sous-Forêts. Geotherm Energy. 2014;2(1):17.

Maurer V, Cuenot N, Gaucher E, Grunberg M, Vergne J, Wodling H, Lehujeur M, Schmittbuhl J. Seismic monitoring of the Rittershoffen EGS project (Alsace, France) In: Proceedings world geothermal congress. 2015.

McDermott Cl, Lodemann M, Ghergut I, Tenzer H, Sauter M, Kolditz O. Investigation of coupled hydraulic-geomechanical processes at the KTB site: pressure dependent characteristics of a long term pump test and elastic interpretation using a geomechanical facies model. Geofluids. 2006a;6(1):67-81.

McDermott Cl, Randriamanjatosoa AL, Tenzer H, Kolditz O. Simulation of heat extraction from crystalline rocks: the influence of coupled processes on differential reservoir cooling. Geothermics. 2006b;35(3):321-44.

Murphy HD. Convective instabilities in vertical fractures and faults. J Geophys Res. 1979;84:6121-30.

Olasolo P, Juárez M, Morales MP, Liarte IA. Enhanced geothermal systems (EGS): a review. Renew Sustain Energy Rev. 2016;56:133-44.

Pérez-Flores MA, Schultz A. Application of 2D inversion with genetic algorithms to magnetotelluric data from geothermal areas. Earth Planets Space. 2002;54(1):607-16.

Pribnow D, Schellschmidt R. Thermal tracking of upper crustal fluid flow in the Rhine Graben. Geophys Res Lett. 2000;27(13):1957-60.

Pribnow D, Fesche W, Hägedorn F. Heat production and temperature to $5 \mathrm{~km}$ depth in HDR site in Soultz-sous-Forêts. GGA: Technical report; 1999.

Pruess K. Modeling of geothermal reservoirs: fundamental processes, computer simulation and field applications. Geothermics. 1990;19(1):3-15.

Rowe AM, Chou JCS. Pressure-volume-temperature-concentration relation of aqueous sodium chloride solutions. J Chem Eng Data. 1970;15(1):61-6.

Rummel F. Physical properties of the rock in the granitic section of borehole GPK1 Soultz-sous-Forêts. Geothermal energy in Europe: the Soultz Hot Dry Rock Project. 1992. p. 199-216.

Sambridge M. Geophysical inversion with a neighbourhood algorithmi. searching a parameter space. Geophys J Int. 1999;138(1):479-94

Sanjuan B, Scheiber J, Gal F, Touzelet S, Genter A, Villadangos G. Inter-well chemical tracer testing at the Rittershoffen geothermal site (Alsace, France). In: European Geothermal Congress. 2016.

Sanyal SK, Butler SJ, Swenson D, Hardeman B. Review of the state-of-the-art of numerical simulation of enhanced geothermal systems. Trans Geotherm Resourc Council. 2000;28:181-6.

Sausse J. Hydromechanical properties and alteration of natural fracture surfaces in the Soultz granite (Bas-Rhin, France). Tectonophysics. 2002;348(1):169-85.

Scheck-Wenderoth M, Cacace M, Maystrenko YP, Cherubini Y, NoackV, Kaiser BO, Sippel J, Lewerenz B. Models of heat transport in the Central European basin system: effective mechanisms at different scales. Marine Petrol Geol. 2014:55(1):315-31.

Schill E, Genter A, Cuenot N, Kohl T. Hydraulic performance history at the soultz egs reservoirs from stimulation and longterm circulation tests. Geothermics. 2017;70:110-24.

Schindler M, Baumgärtner J, Gandy T, Hauffe P, Hettkamp T, Menzel H, Penzkofer P, Teza D, Tischner T, Wahl G. Successful hydraulic stimulation techniques for electric power production in the Upper Rhine Graben, Central Europe. In: Proceedings world geothermal congress. 2010.

Tarantola A. Inverse problem theory. Methods for model parameter estimation SIAM Philadelphia, ISBN-13: 9780898715729. 2004.

Tester JW, Anderson BJ, Batchelor AS, Blackwell DD, Dipippo R, Drake EM, Garnish J, Livesay B, Moore CM, Nichols K, Toksöz MN, Veatch J. The future of geothermal energy, Impact of Enhanced Geothermal Systems on the United States in the 21st century. MIT report: Technical report; 2006. 
Tomac I, Sauter M. A review on challenges in the assessment of geomechanical rock performance for deep geothermal reservoir development. Renewable Sustain Energy Rev. 2017;1:1. https://doi.org/10.1016/j.rser.2017.10.076.

Turcotte DL, Schubert G. Geodynamics. Cambridge: University Press Cambridge; 2014.

Valley B. The relation between natural fracturing and stress heterogeneities in deep-seated crystalline rocks at Soultzsous-Forêts (France). PhD thesis, ETH Zürich. 2007.

Vallier B, Magnenet V, Schmittbuhl J, Fond C. Two and three dimensional THM modelling of the Soultz-sous-Forêts geothermal reservoir: a comparison In: European Geothermal Congress 2016. 2016.

Vallier B, Magnenet V, Schmittbuhl J, Fond C. THM large scale modeling of the hydro-thermal circulation in the deep geothermal reservoir of Soultz-sous-Forêts (France) In: European Geothermal Workshop 2017, Karlsruhe, Germany. 2017. p. 23-4.

Vidal J, Genter A, Schmittbuhl J. Pre- and post stimulation characterization of geothermal well GRT-1, Rittershoffen, France: insights from acoustic image logs of hard fractured rocks. Geophys J Int. 2016a;206(2):845-60.

Vidal J, Genter A, Chopin F, Dalmais E. Natural fractures and permeability at the geothermal site Rittershoffen, France In: European geothermal congress. 2016b.

Vidal J, Patrier P. Genter A, Beaufort D. Occurences of clay minerals in permeable fracture zones in the granitic basement of geothermal wells at Rittershoffen, France In: 42nd Workshop on geothermal engineering Stanford University, Stanford, California, February 13-15. 2017.

Vogt C. Stochastic inversion of the tracer experiment of the enhanced geothermal system demonstration reservoir in Soultz-sous-Forêts—revealing pathways and estimating permeability distribution. Geothermics. 2012;42(1):1-12.

Watanabe K, Takahashi H. Fractal geometry characterization of geothermal reservoir fracture networks. J Geophys Res. 1995; 100:521-8.

Willis-Richards J, Wallroth T. Approaches to the modelling of HDR reservoirs: a review. Geothermics. 1995;24(3):307-32.

Willis-Richards J, Watanabe K, Takahashi H. Progress toward a stochastic rock mechanics model of engineered geothermal systems. J Geophys Res. 1996;101:17481-96.

Zaytsev ID, Aseyev GG. Properties of aqueous solutions of electrolytes. Boca Raton: CRC Press; 1992.

Zienkiewicz OC, Taylor RL, Taylor RL, Zhu J. Finite element method: its basis and fundamentals. Amsterdam: Elsevier Incorporated; 2013

\section{Submit your manuscript to a SpringerOpen ${ }^{\odot}$ journal and benefit from:}

- Convenient online submission

Rigorous peer review

Open access: articles freely available online

- High visibility within the field

- Retaining the copyright to your article

Submit your next manuscript at $\boldsymbol{\Delta}$ springeropen.com 